\title{
O ASSASSINATO DE TROTSKY À LUZ DA HISTÓRIA
}

\author{
Osvaldo Coggiola \\ Prof. Depto. de História - FFLCH/USP
}

RESUMO: Sessenta anos depois de acontecido, o assassinato de Leon Trotsky continua a ser apresentado como uma vingança pessoal ou como um episódio final da "luta pela sucessão de Lênin" na URSS. Este artigo procura recuperar a dimensão histórica do fato, situando-o no contexto, não apenas da situação da URSS, mas do cinjunto da situação mundial, na década de 30 .

PALAVRAS-CHAVE: Comunismo, stalinismo, burocracia, revolução, marxismo

ABSTRACT: Since it happenned, sixty years ago, Leon Trotsky's assassination still is analysed as a personal vengeance or as the final episode of the "struggle for Lenin's sucession" in the Soviet Union. This article recovers the historical dimension of this fact, placing it on the context of the Soviet Union as well as of the world in the 1930's.

KEYWORDS: Communism, Stalinism, Burocracy, Revolution, Marxism.

L'homme qu'a fait taire Trotsky sans l'regarder en face

A jamais touché d'royalties sur l'pic à glace

Déposé l'brevet à sa place

(Boris Bergman e Maxime Le Forestier, Photo-finish, 1995) 
Murió Trotsky asesinado de la noche a la mañana porque habían premeditado venganza tarde o temprana. Pensó en México, este suelo hospitalario y grandioso, para vivir muy dichoso bajo el techo de este cielo. Por fin lo venció el destino en su própia residencia, donde el cobarde asesino le arrancó ahí sua existencia.

Un zapapico alpinista este asesino llevó, y al estar solo con Trotsky a mansalva lo atacó.

Fué un día martes por la tarde esta tragedia fatal, que ha conmovido al país y a toda la capital

(Gran Corrido Leon Trotsky, anônimo popular mexicano, 1940)

Era duro e severo grave tinha a voz e era de aço sua apostasia. (Era, não. É, que ainda hoje em dia está o homem inteiro.) 
Leon Trotsky morreu em 21 de agosto de 1940, das sequielas do ataque de que fora vítima na véspera, na sua casa em Coyoacán (México). O assassinato do dirigente da Revolução de Outubro, criador do Exército Vermelho, inimigo público número um de Stalin e seu regime, comoveu o mundo inteiro. Rapidamente, porém, ele desapareceu dos comentários e manchetes de jornal, abafado pelos acontecimentos da "guerra européia" (futuramente batizada de Segunda Guerra Mundial) iniciada quase que exatamente um ano antes, com a invasão conjunta da Polônia pelos exércitos da Alemanha e da URSS, invasão, por sua vez, resultado do Pacto Hitler-Stalin celebrado em 1939 (a partilha da Polônia era uma das suas cláusulas secretas), pacto ao qual, como veremos, o próprio assassinato se vinculava por mais de um fio.

\section{A imagem da história}

Fruto dessa circunstância, o assassinato do homem que simbolizava a intransigência revolucionária na primeira metade do século XX não chegou a ocupar, no imaginário popular, um lugar semelhante ao do assassinato de Ernesto "Che" Guevara, cometido em 1967. Com os anos, porém, o fato cresceu até tornar-se um símbolo do drama do século. Desde canções populares até a alta literatura fizeram dele um momento-chave da história contemporânea, no sentido literal ou metafórico, a exemplo do que fez o principal, e seguramente melhor, romance de Jorge Semprún (SEMPRÚN, 1970). O próprio cinema (Trotsky tinha sido o primeiro líder bolchevique a ver nele "a arte popular do século") o registrou diversas vezes, com destaque para a produção de Joseph Losey, com Richard Burton no papel de Trotsky, Alain Delon no de seu assassino (Ramón Mercader del Rio) e uma muito improvável Romy Schneider no papel da fisicamente pouco agraciada Sylvia Ageloff, a militante de origem russa, irmã de uma secretária de Trotsky, que, seduzida por Mercader, acabou facilitando involuntariamente o ingresso do homicida no entourage imediato do revolucionário russo.

Sessenta anos depois, está tudo esclarecido, visto sob o ângulo da história? Não é o que parece, pelo menos à leitura do recente e demasiadamente famoso livro de Eric Hobsbawm sobre o "curto século XX", no qual o historiador inglês se refere, com bastante superficialidade, ao regime stalinista na URSS e seus opositores: "Poucos desses centros dissidentes contavam muito do ponto de vista político. De longe o mais prestigioso dos hereges, o exilado Leon Trotsky -co-líder da Revolução de Outubro e arquiteto do Exército Vermelho- fracassou por completo em seus esforços políticos. Sua IV Internacional, destinada a competir com a stalinizada Terceira Internacional, foi praticamente invisível. Quando foi assassinado por ordem de Stalin em seu exílio no México, em 1940, a importância política de Trotsky era insignificante" (HOBSBAWM, 1994, p. 80).

Certamente, em 1940, Trotsky estava isolado, tanto quanto, digamos, Marx o estava depois da Comuna de Paris, Lenin no início da Primeira Guerra Mundial, Mao nas montanhas de Yenan, ou Fidel Castro no seu exílio -também mexicano- antes da expedição do Granma. A apreciação de Hobsbawm comporta os seguintes pressupostos: 1) Trotsky carecia de qualquer importância política nesse período; 2) Seu assassinato não teve, portanto, nenhum vínculo com os acontecimentos políticos correntes, e nenhuma influência neles; 3) Ele foi fruto de uma vingança pessoal de Stalin, sem que o estamento dirigente da URSS tivesse, seja qualquer intervenção, seja qualquer interesse no assunto. Mas justamente esses pressupostos são mais do que questionáveis.

A hipótese de que o assassinato resultou da consumação de uma vingança pessoal do seu arqui-inimigo, o todo-poderoso ditador Josef Stalin, não é surpreendente, se levarmos em conta que o mandante do assassino (este, um stalinista catalão infiltrado no círculo de Trotsky pela NKVD, a polícia política so- 
viética) já tinha demonstrado sua falta de escrúpulo com relação à vida alheia e que estas características doentio-vingativas de Stalin já tinham inclusive sido apontadas no ensaio biográfico que the consagrara o próprio Trotsky (segundo este, Stalin não procurava "atingir as idéias dos seus adversários, mas sim o seu cérebro") (TROTSKY, 1973).

Esta versão corrente tende a apagar as enormes divergências entre Stalin e Trotsky, e não raro, apoia-se na suposição de que Trotsky teria procedido do mesmo modo caso Stalin estivesse em seu lugar. Ela descarta a possibilidade de que o assassinato fosse o recurso extremo de uma luta política entre forças sociais contraditórias. A importância histórica do crime ficaria, então, reduzida à de testemunho da psicopatologia assassina elevada à razão de Estado. Ou seja, teria uma importância apenas exemplar, onde só a figura do assassino ganharia contornos históricos, sendo a vítima um objeto passivo, com funções de exemplo de ocasião.

\section{Uma vingança?}

Em maio de 1989, quando ainda existia a URSS, a revista soviética Sputnik -uma espécie de porta-voz oficial da glasnost e da perestroika - publicou um artigo intitulado "Trotsky: demônio da revolução", onde o modernismo democratizante dos gorbachovianos não resistia à prova dos fatos, pois nele eram retomadas contra o velho líder bolchevique as mesmas calúnias, com o mesmo fundo religioso (demônio), elaboradas mais de meio século antes pelo chefe todo-poderoso, o ex-seminarista georgiano Stalin. Depois, segundo a própria revista conta, "recebemos muitas cartas sobre esta personalidade" (Trotsky), cujo teor imaginamos pelo fato de Sputnik ter sido obrigada a publicar algum tempo depois um novo artigo, "Trotsky: um rosto por trás do vitral da história”, onde foram admitidos, com visível constrangimento, alguns fatos elementares, como o papel central e decisivo de Trotsky na Revolução de $\mathrm{Ou}$ - tubro e na criação e direção do Exército Vermelho (VASSETSKI, 1990).

Na conclusão do artigo, no entanto, a emergência da ditadura stalinista era apresentada como produto da adoção por Stalin das idéias de... Trotsky ("seus métodos deixam de se diferenciar do plano trotskista"), isto porque "a guerra entre estes dois inimigos mortais -Trotsky e Stalin-, não foi só uma luta de idéias. Ambos estavam imbuídos de igual demonismo [!], ambos procuravam sub-rogar o leninismo pelo seu próprio “ismo"'. Como se pode notar, continuava imperando nos círculos dirigentes uma concepção idealista-religiosa para explicar o fato capital da história soviética: a burocratização do Estado, encarnada na ditadura de Stalin.

Pois, para o marxismo, as lutas ideológicas e políticas nunca foram a expressão da luta entre anjos e demônios, mas do choque entre forças e interesses sociais conflitantes. Na concepção de Sputnik, o assassinato de Trotsky teria sido produto da sua "inimizade mortal" com Stalin, o que deixa sem explicação o massacre de milhares de trotskistas e de outros opositores nos campos siberianos e pelo mundo afora, e inocenta o Estado (com sua coluna vertebral, a polícia política), pois o assassinato seria apenas conseqüência de uma vingança pessoal.

Na medida em que a interpretação referida apoiase em elementos reais (a conturbada psique staliniana), ela adquire valor explicativo, apesar de ocultar muito mais do que esclarece acerca das causas do crime. Ainda assim, muita coisa fica sem explicação: por que, apesar de Stalin comandar pessoalmente a caçada ao exilado Trotsky, esta foi transformada em "assunto de Estado", mobilizando desde a diplomacia russa, que pressionou o governo francês de Laval para que não fosse concedido asilo político a Trotsky, no quadro do "acordo Laval-Stalin", até a espinha dorsal do Estado staliniano, a GPU (depois NKVD e, finalmente, KGB), onde se constituiu uma "seção Trotsky", com dezenas de funcionários e oficiais militares consagrados à per- 
seguição? Por que Stalin fez do assassinato uma verdadeira antecipação da "crônica de uma morte anunciada", fazendo de Trotsky réu principal in absentia dos mortíferos "Processos de Moscou" (1936-1938), e não desistindo sequer depois do público fracasso da tentativa homicida dos stalinistas mexicanos, comandados pelo pintor David Alfaro Siqueiros?

\section{Trotsky na década de 30}

O exilado bolchevique de Coyoacán estava bem longe de ser uma personagem política insignificante naquele 1940. A imagem contrária chegou até nós, não só através das ressonâncias míticas da obra do principal biógrafo de Trotsky, Issac Deutscher, cujo título, O Profeta Desterrado, sugere que os últimos anos de vida de Trotsky foram uma espécie de travessia no deserto. Mas, na década de 30, não escapava a nenhum observador inteligente, a instabilidade das bases das ditaduras nazista e stalinista (os dois pilares da Meia-Noite do Século, na feliz definição de Victor Serge) e o papel que, nesse quadro político, podia jogar o fundador, junto com Lenin, do Estado Soviético, o criador e chefe histórico do Exército Vermelho. Em 1939, o pacto Hitler-Stalin tendia a reforçar ambos os governos, colocando a Europa inteira sob a bota totalitária do nazi-fascismo e do stalinismo. Mas a instabilidade política internacional também varreu esse pacto, em junho de 1941, quando a Alemanha invadiu a URSS. A Segunda Guerra Mundial, ao mesmo tempo que adiou a crise dos regimes totalitários, tornou-a mais catastrófica.

O constrangimento com que, nos anos 30, meia dúzia de governos ocidentais se desembaraçaram de Trotsky, a despeito das elementares normas de direito de asilo (para aquele, o mundo se transformara em "o planeta sem visto de entrada", título dado por Trotsky a esse período da sua vida em sua autobiografia) até o líder soviético ser aceito num país ainda governado por pessoas que tinham lutado pela demo- cracia com armas na mão, aquele constrangimento teve razões "diplomáticas", vinculadas ao peso político nacional e internacional que Trotsky possuía. De acordo com uma ex-dirigente da Internacional Comunista, "o governo francês deu a Trotsky o direito de residir na França no mesmo momento em que se aproximava de Moscou. Cabe supor que tinham informações acerca da fragilidade da situação de Stalin, e do reagrupamento da oposição (na URSS). Considerava-se possível um retorno de Trotsky a Moscou, e pode ter sido vista como uma boa política, em 1933, dar a Trotsky um tratamento amistoso, com um olho posto numa futura reorganização do Politburo russo" (FISCHER, 1985).

Na URSS a influência de Trotsky crescia entre os opositores anti-stalinistas. Mas os trotskistas organizados estavam na sua quase totalidade deportados na Sibéria, onde as metralhadoras acabariam com eles até o início da Segunda Guerra. Na Espanha, os trotskistas e o POUM (Partido Operário de Unificação Marxista) seriam perseguidos na própria República em guerra contra o franquismo, sendo o principal líder do POUM, o ex-dirigente da Internacional Comunista (IC), Andreu Nin, seqüestrado e assassinado por agentes da GPU. Quando, em 1938, os partidários de Trotsky se reuniram em Paris para fundar a IV Internacional, que deveria substituir a III Internacional stalinizada (que seria dissolvida em 1943) Stalin mandou o seu recado: o principal organizador da reunião, Rudolph Klement, apareceu boiando esquartejado no Sena. O mesmo destino coube a Ignace Reiss, importante agente da GPU-NKVD, que rompeu com Stalin e se aproximou de Trotsky, sendo assassinado na Suíça (não sem antes ter enviado uma carta ao Politburo do PCUS, anunciando a sua ruptura e a sua adesão à IV Internacional, fato que, segundo Trotsky, como veremos, foi provavelmente a imprudência que lhe custou a vida). ${ }^{1}$

${ }^{1}$ Cf. as memórias da mulher de Ignace Reiss (codinome de Ignacy Poretski, militante comunista orginário da Galitzia austro-húngara, 
Mas, apesar de assassinatos e perseguições, no mesmo ano de 1938, o jornal francês Paris-Soir transcrevia em off as preocupações surgidas numa reunião entre Hitler e o embaixador francês Coulondre: a de que, em caso de uma nova guerra mundial (que explodiria em breve) dela saísse vitorioso, não qualquer dos blocos envolvidos, mas... "Monsieur Trotsky", ou seja, que num processo análogo ao do final da primeira guerra, a guerra mundial se desdobrasse em guerra civil internacional ${ }^{2}$.

A Segunda Guerra foi deflagrada e terminou com sintomas inequívocos de guerra civil (por exemplo, a poderosa presença de partisanos irregulares na França, Itália, Grécia e Iugoslávia) mas sem a vitória do previamente morto Trotsky nem dos seus partidários. A dizimação destes continuou durante a Segunda Guerra: os dirigentes da importante organização trotskista belga (o intelectual Abraham Leon e o sindicalista Leon Lesoil) foram mortos pelos nazistas; o ex-dirigente do PC italiano, Pietro Tresso, "Blasco", engajado no maquis francês, foi morto por seus "companheiros" do PC francês, o que foi denunciado pelo historiador Marc Bloch, resistente insuspeito de “trotskismo", fuzilado em 1943 pelos nazistas 3 .

depois polonesa, por 16 anos agente do GPU e da NKVD; Poretski também usava o codinome "Ludwig"): Poretski, 1969. A opinião de Trotsky se encontra num artigo incluído como prefácio a esse livro. ${ }^{2}$ Coulondre, 1950. De acordo com Nicholas Mosley (1972): “O embaixador francês na Alemanha, Coulondre, teve uma entrevista com Hitler, em 1939, e falou no tumulto e nas revoluções que poderiam seguir-se a uma guerra. Relatou que disse a Hitler: vocês se julgam vitoriosos... mas já pensaram em outra possibilidade, a de que a vitória seja de Trotsky? Hitler pulou 'como se tivesse levado um soco no estômago' e gritou que esta era mais uma razão para que a França e a Inglaterra não entrassem em guerra com a Alemanha."

${ }^{3} \mathrm{Um}$ relato pormenorizado desse fato, incluindo a identidade dos militantes do PCF que assassinaram Pietro Tresso, encontra-se em: Broué e Vacheron, 1997.
O “perigo Trotsky", o seu peso político potencial nos acontecimentos, não se devia só, nem principalmente, ao seu relevante papel na fundação do Estado soviético, ainda vivo na memória de milhões. $\mathrm{O}$ assassinato de Trotsky inscreveu-se como o mais importante no quadro da dizimação de toda uma corrente política, a única que sustentava perante a próxima segunda guerra, uma política semelhante à defendida pelos bolcheviques durante a primeira, propondo ao mesmo tempo uma revolução política anti-burocrática contra o stalinismo na URSS. Foi a peça-mestra de uma tentativa, até certo ponto bem sucedida, de neutralizar essa corrente diante da catástrofe mundial.

\section{A tentativa de maio}

As etapas prévias e os fatos do próprio assassinato de Trotsky são bem conhecidos. Na noite de 24 de maio de 1940, aproximadamente 25 indivíduos disfarçados de policiais conseguiram entrar na residência de Coyoacán, seqüestrando previamente o guarda pessoal de Trotsky, Robert Sheldon Harte, que estava de sentinela, e amarrando os policiais encarregados de vigiar a casa. Dirigindo-se ao dormitório em que descansavam Trotsky e sua mulher, começaram a disparar com metralhadoras das janelas até as duas portas da casa, sobre as camas. Mas, não alcançados pelos primeiros disparos, o líder revolucionário e sua companheira, Natalia Sedova, conseguiram chegar, arrastando-se sobre o chão, até um canto do quarto. $\mathrm{O}$ fogo cruzado durou ainda alguns minutos e, em certo momento, um dos atiradores entrou na casa e descarregou sua metralhadora sobre as camas. Ele saiu logo, aparentemente julgando consumado seu objetivo, e jogando uma bomba incendiária no cômodo contíguo, onde se encontrava o neto de Trotsky, um menino de poucos anos que se salvou da morte da mesma forma que seus avós (embora ficasse ferido num pé).

Os atiradores afastaram-se, cobrindo sua retirada com o fogo das metralhadoras, em dois carros que de- 
pois foram abandonados nas ruas do México. Um deles pertencia ao pintor Diego Rivera, ex-amigo e anfitrião de Trotsky quando da sua chegada ao México, cujo motorista foi detido, apesar daquele fugir para Hollywood, de onde regressou ao saber que não o implicavam no atentado. Trotsky havia rompido todo tipo de relações com Diego Rivera em 1938, quando este se submeteu ao partido reacionário do general Almazán. Posteriormente, se filiaria ao Partido Comunista mexicano. Natalia Sedova disse a respeito dele que, "de todos nossos antigos camaradas, é o único que posteriormente se converteu de forma escandalosa ao stalinismo". Quando se filiou ao PCM, Rivera justificou sua intervenção ante Cárdenas para que este concedesse asilo a Trotsky, em 1936, dizendo que respondia ao ânimo de atraí-lo para facilitar sua eliminação (!).

As investigações policiais, apesar de um começo errado, provocado pela suspeita do chefe da polícia Sänchez Salazar de que se tratasse de um "auto-atentado" (Cf. SÁNCHEZ SALAZAR, 1955), se encaminharam de forma certeira. É preciso assinalar a atitude da imprensa staliniana, dirigida pelo advogado e líder sindical Vicente Lombardo Toledano, a quem Trotsky acusou ante o Procurador Geral da República de ser cúmplice moral do atentado. A orquestração dessa imprensa demonstrou, sem sombra de dúvidas, que Toledano conhecia perfeitamente a preparação e os detalhes do atentado antes da própria polícia. Em junho, esta conseguiu esclarecer plenamente a trama, provando a culpa de vários membros do Partido Comunista Mexicano, cujas confissões proporcionaram as pistas para chegar aos principais organizadores: eram estes o conhecido pintor David Alfaro Siqueiros e seu secretário Antonio Pujol; também participaram David Serrano Andonaegui, membro do Comitê Central do partido, Néstor Sánchez Hernández, o qual juntamente com Siqueiros, havia atuado nas "brigadas internacionais" da Espanha, e outros membros do PCM. Mas não foi possível chegar a estabelecer, naquele momento, a identidade de um "judeu francês" que havia estado presente durante a exe- cução do atentado e que, com toda probabilidade, era o agente da GPU. Posteriormente, Julián Gorkin mostrou diversas provas reunidas por ele, buscando demonstrar que aquele judeu francês seria o doutor Gregori Rabinovitch, ex-presidente da Cruz Vermelha Soviética de Chicago, instituição que em outro momento serviu para ocultar as atividades da GPU. Imediatamente depois do assalto de 24 de maio, Rabinovitch retornou aos Estados Unidos, mas na capital mexicana caiu seu mais próximo colaborador, Vittorio Vidali, antigo agente da GPU, conhecido na guerra civil espanhola como "comandante Carlos" ou "Carlos Contreras".

A 25 de junho, Néstor Sánchez Hernández conduziu a polícia até uma casa situada em Tlalminalco, deserto dos Leões, onde se encontrou o cadáver de Robert Sheldon Harte, que havia sido assassinado enquanto dormia. A casa estava alugada pelos irmãos Luis e Leopoldo Arenal, cunhados de Siqueiros. Este e Pujol, fugitivos, foram presos em 4 de outubro de 1940, quando Trotsky já estava morto. Em junho, o primeiro havia enviado uma carta aos jornais, dizendo: "O Partido Comunista não buscou, ao cometer o atentado, mais do que provocar a expulsão de Trotsky do México; os inimigos do Partido Comunista podem esperar ser tratados do mesmo modo." Esta declaração tendia, provavelmente, e reconhecendo uma culpabilidade já inegável, a encobrir a GPU, querendo fazer com o que o atentado passasse por um arreba-

\footnotetext{
${ }^{4}$ A identidade do "judeu francês" foi objeto de controvérsias. Hoje, a partir do depoimento do ex-agente Pavel Sudoplátov (P. e A. Sudoplátov, 1994), neste ponto confiável, parece claro que se tratava de Leonid A. Eitingon, codinome na NKVD do judeu-russo Naum Isákovich, que tinha "servido" na França como "Pierre", também como "Tom", e na Espanha, durante a guerra civil, como "general Kotov". Sudoplátov nega que Eitingon fosse amante ou marido de Caridad Mercader, mãe do assassino de Trotsky. Atuou no México, segundo o ex-agente, "com um falso passaporte interno francês de um judeu sírio que padecia de uma doença mental".
} 
tamento de cega paixão política, para o qual se anunciava "ingenuamente" que se perpetrariam outros.

\section{O assassinato}

Trotsky salvou-se dessa primeira tentativa com extrema dificuldade. Mas sabia que a tentativa de assassinato se repetiria indubitavelmente. Assim ele o declarou à imprensa mexicana. Reforçou-se então a guarda policial em Coyoacán e se fortificou a casa, que chegou a parecer uma prisão ou uma fortaleza.

No seu livro de memórias This is My Story, o exdirigente do PC dos EUA, Louis Budenz, convertido ao catolicismo em 1946, relatou que no final de 1936, ao se conhecer a próxima partida de Trotsky para o México, expulso do seu precário refúgio na Noruega, o líder do PC americano, Earl Browder, discutiu com um de seus ajudantes, Jack Stachel, a possibilidade do assassinato. Budenz, que reconheceu ter sido um dos agentes da GPU que operavam nos EUA, declara que um deles lhe pediu para encontrar uma pessoa simpatizante, que pudesse colocar um homem de confiança em relação com os trotskistas americanos. Budenz designou então a Ruby Weill, colaboradora de uma publicação simpatizante do PCA, que mantinha relações de amizade com uma jovem militante do Socialist Workers Party (SWP, Partido Socialista dos Trabalhadores, o partido trotskista dos EUA), Sylvia Ageloff, de origem russa, cuja irmã Ruth havia trabalhado durante algum tempo como secretária de Trotsky em Coyoacán. Ambas fizeram juntas uma viagem à França em 1938, na qual Weill colocou sua amiga em contato com um jovem, supostamente belga, que se dizia filho de diplomata, rico, grande viajante e que desejava ser jornalista: "Jacques Mornard". Este cortejou Sylvia e se tornou seu amante.

Em janeiro de 1939, ambos fizeram uma viagem ao México, onde encontraram os velhos amigos e hóspedes de Trotsky, Alfred e Marguerite Rosmer, os quais Mornard conduziu várias vezes em seu au- tomóvel a Coyoacán. Como Trotsky observasse que era descortês deixar o marido de Sylvia na porta, convidou-o a entrar no jardim. Três dias depois do atentado de 24 de maio, Mornard conduziu os Rosmer em seu automóvel até Veracruz; antes de partir, compartilhou pela primeira vez o café da manhã com os habitantes da casa.

Desde então, Mornard pôde entrar na casa de Trotsky como uma pessoa de confiança. Fazia breves visitas, Trotsky o atendia por cortesia alguns minutos no jardim, enquanto dava de comer a seus coelhos. Em junho de 1940, Mornard foi aos EUA, de onde regressou em agosto, em estado de extremo nervosismo e doente. Provavelmente já lhe haviam dado a ordem de executar o assassinato, visto o fracasso da tentativa prévia de Siqueiros. Uma semana antes do assassinato, Sylvia e seu marido fizeram uma visita a Coyoacán, oportunidade em que esta discutiu com Trotsky em favor dos pontos de vista da minoria do Socialist Workers Party, encabeçada por Max Schachtman. "Mornard", que apenas participou na discussão e não pareceu muito interessado, escreveu um artigo curto a respeito, mostrou-o a Trotsky, que o considerou primário. "Mornard" escreveu então uma segunda versão, que a 20 de agosto de 1940 levou para Trotsky para lhe pedir seu parecer.

Uma vez no gabinete deste último, Mornard levou a cabo seu atentado, enquanto Trotsky estava lendo seu escrito, desferindo um golpe de picão no crânio do revolucionário. Quando se apressava para repetir o golpe, Trotsky se lançou sobre ele, conseguindo impedí-lo. Com o grito de Trotsky, os guardas e sua esposa vieram ajudá-lo. Trotsky, com o rosto ensangüentado, sem lentes e com as mãos caídas, apareceu no vão da porta. Indicou com dificuldade que não se devia matar "Jacson" ("Mornard" tinha sido apresentado a ele como "Frank Jacson") ${ }^{5}$, sem conseguir que ele falasse. $\mathrm{O}$ assassino, ao ser golpeado pelos guardas, gritou: "Eles têm a minha mãe... Eles prenderam a minha mãe. Sylvia não tem nada a 
ver com isso... Não, não é a GPU. Eu não tenho nada a ver com a GPU."

Um médico declarou que a ferida de Trotsky não era grave, mas este se dirigiu a seu secretário Joseph Hansen (dirigente do SWP) em inglês, dizendo-lhe com um gesto da mão em seu coração: "Eu sinto aqui que é o fim... Desta vez eles conseguiram.”. Depois de uma intervenção cirúrgica, Trotsky faleceu a 21 de agosto pela noite. No bolso do assassino se encontrou uma carta na qual este tentava justificar seu ato como sendo o de um "trotskista desiludido com seu mestre", que lhe teria exigido deslocar-se para a URSS a fim de cometer atentados e assassinar o próprio Stalin (!), além de proibí-lo de se casar com Sylvia; tanto os conceitos como o estilo da mesma eram típicos das "provas" forjadas pela NKVD-GPU. Já se haviam encontrado cartas semelhantes ao lado do cadáver de vítimas daquela, como o próprio Rudolph Klement. A de "Mornard" repetia os "argumentos" do fiscal Vichynsky nos Processos de Moscou (Trotsky como organizador de atentados na URSS, visando eliminar Stalin e todos os dirigentes do país). A carta estava datilografada, mas a data tinha sido acrescentada a mão, o que era outro indício do seu caráter forjado. Mais de cinquenta anos depois, o coordenador geral do assassinato, o agente da NKVD Pável Sudoplátov, admitiu o fato: "Era importante deixar entrever uma motivação que pudesse desprestigiar a imagem de Trotsky e desacreditar seu movimento" (P. e A. SUDOPLÁTOV, 1994, p. 115.).

\footnotetext{
5 "Mornard" explicara a Sylvia Ageloff que comprara um passaporte canadense a nome de "Frank Jacson" para sair da Bélgica se livrando do serviço militar, passaporte que usou para entrar nos EUA e no México.
}

\section{As evidências imediatas}

O velório de Trotsky na cidade do México durou cinco dias. 300 mil pessoas foram se despedir pela última vez do revolucionário. O presidente Lázaro Cárdenas e sua esposa, que tinham se abstido de conhecer pessoalmente Trotsky, visitaram Natalia Sedova e expressaram sua indignação pelo crime, assegurando que sabiam muito bem que cartas do tipo da encontrada no bolso do assassino haviam sido fabricadas, e que ela não devia se inquietar a esse respeito.

A identidade de "Jacson-Mornard", que este conseguiu ocultar durante anos, apesar de sua origem belga e demais referências serem claramente falsas, foi esclarecida por um médico mexicano, o Dr. Quiroz, que consultou em 1950 (por ocasião de um congresso médico na Espanha) fichas da polícia espanhola, que coincidiam com as do assassino no México. "Jacson Mornard" na verdade chamava-se Ramón Mercader del Río e era filho da agente da GPU, Caridad Mercader ${ }^{6}$. Condenado a 20 anos, o assassino dispôs, durante a sua permanência na prisão de Lecumberri, de abundantes fundos de proveniência desconhecida, assegurando-se assim de um tratamento privilegiado na penitenciária.

Demonstrou-se, também, sua conexão com Siqueiros. Numa determinada ocasião, antes do crime, em que Sylvia Ageloff lhe perguntou por sua direção comercial, deu as senhas de uma oficina no edifício Ermita, da cidade do México, que logo se comprovou estar alugada em nome de Siqueiros. Mercader foi libertado em 1960, dirigindo-se a Cuba, onde o recém instalado (um ano e meio) regime de Fidel Castro lhe negou o asilo político. Mercader foi então para a Checoslováquia, e daí para a URSS, onde recebeu a "Ordem ao Mérito" de Lenin. Esquecido

\footnotetext{
${ }^{6} \mathrm{O}$ estabelecimento definitivo dessa identidade, baseado em todas as provas e documentos do caso, foi feito por Levine, 1960.
} 
depois, voltou para a Checoslováquia e aí, segundo alguns, morreu de um câncer no estômago em finais da década de 70 (Sudoplátov sustenta que morreu em Cuba em 1978, depois de "trabalhar como assessor de Fidel Castro"-!-, sendo seu cadáver transportado para Moscou, onde estaria enterrado como "Ramón I. López”).

Em 1966, o jornal belga Le Soir anunciou a morte do verdadeiro Jacques Mornard, cuja identidade Mercader "expropriara" e que, em vida, negou sempre ter tido qualquer relação ou conhecimento de Mercader. Sylvia Ageloff, sua ex-mulher "trotskista", mudou-se depois do assassinato para Nova Iorque, onde nunca mais voltou a falar no assunto, casandose com outro militante trotskista que se tornaria conhecido como professor de literatura na NYU (New York University).

\section{Um exilado incomum}

Levando-se em conta que a Oposição de Esquerda já estava derrotada, na URSS, em 1927, e os métodos empregados por Stalin, pode parecer surpreendente que o assassinato de Trotsky tenha demorado tanto e, sobretudo, que Stalin não o tivesse preso e executado quando aquele ainda se encontrava na URSS, optando por exilá-lo em 1929. Trotsky deu uma explicação para esse fato: "Em 1928, quando fui excluído do partido e exilado na Ásia Central, não era ainda possível se falar em pelotão de execução, nem mesmo em detenção. A geração com a qual eu tinha compartilhado a Revolução de Outubro e a guerra civil estava ainda viva. O Politburo se sentia pressionado por todos os lados.

"Da Ásia central, eu consegui manter contatos diretos com a Oposição [de Esquerda]. Nessas condições, Stalin, depois de vacilar durante um ano, decidiu-se pelo exílio como um mal menor. Pensou que Trotsky, isolado da URSS e sem aparelho e recursos materiais, seria incapaz de fazer qualquer coisa. Além disso, calculou que depois de me desprestigiar perante a população, não teria dificuldades em obter do governo aliado da Turquia o meu retorno a Moscou para o golpe final. Os acontecimentos posteriores, no entanto, demonstraram que era possível, sem aparelho ou recursos materiais, tomar parte na vida política. Com a ajuda de jovens camaradas, estabelecí as bases da IV Internacional, que avança de modo lento mas seguro. Os processos de Moscou de 1936-37 foram organizados para obter minha expulsão da Noruega, isto é, para fazer-me cair nas mãos da GPU. Mas isto não foi possível. Consegui chegar ao México. Sei que Stalin reconheceu diversas vezes que exilar-me tinha sido um erro enorme" (TROTSKY, 1987, vol.24, 103).

Em 1929, Trotsky foi expulso da URSS e enviado manu militari à Turquia, onde, após uma breve passagem por Constantinopla, fixou residência na ilha de Prinkipo. Pouco menos de dois meses antes, a Oposição de Esquerda tinha se manifestado publicamente pela última vez na URSS: "Isto aconteceu a 7 de novembro de 1927, em ocasião de um gigantesco desfile pelo X aniversário da Revolução de Outubro. Um membro do Comitê Central, cujas simpatias se inclinavam por Trotsky, havia decorado o balcão de sua casa com retratos de Lenin, Trotsky e Zinoviev. Ali se reuniram os membros da oposição para aclamar Trotsky. O desfile passaria sob aquele balcão, na esquina das ruas Moskovaia e Tverkaia. Ali se reuniram os membros da oposição para aclamar Trotsky. O balcão foi então ocupado pela GPU e a polícia, os retratos arrancados e os opositores encarcerados" (BUBER-NEUMANN, 1975, 181).

Com a sua expulsão do país, Trotsky passa a se ocupar mais diretamente da organização da Oposição no exterior (ou seja, no interior da Internacional Comunista) mas sem deixar de manter contatos com seus partidários ou simpatizantes na própria URSS, inclusive os membros dos aparelhos de segurança do Estado, às vezes com consequiências trágicas, como no caso do lendário ex-socialista revolucionário Blumkin, membro da GPU: "De passagem por Constantinopla, Blumkin encontrou na rua Leon Sedov (filho de Trotsky). Ljova o levou a Prinkipo. Teve aí uma longa 
conversa com o Velho, e aceitou levar uma mensagem aos oposicionistas russos. Blumkin voltou à Rússia, onde foi detido e executado. Pensou-se que tinha feito confidência do seu encontro ao seu amigo Radek, que o teria entregue. Outros dizem que Radek, temeroso da confidência, lhe aconselhou desastradamente confiar em Ordjonikidzé, presidente da Comissão de Controle e amigo comum a ambos. Outros, enfim, até falaram na traição de uma mulher" (ROSENTHAL, 1975, p. 103).

\section{Oposição e assassinatos}

A execução de Blumkin foi, talvez, a primeira de uma longa série, que iria dizimar quase todos os protagonistas relevantes do período da revolução e guerra civil de 1917-1921. Cronologicamente, aquela coincide com o início da repressão em massa, que começa com a liquidação da "Oposição de Direita" (Bukharin, Tomsky, Rykov) e a coletivização forçada: "O princípio dos campos de trabalho 'corretivo' fora, na origem, fundado para reeducar os criminosos de direito comum e os contra-revolucionários, fazendo-os trabalhar no interesse da coletividade. Até 1929 os campos foram pouco numerosos e não tinham uma população considerável. O número de campos e de deportados cresceu a partir de 1930, por causa da repressão contra os kulaks e contra todos os camponeses hostis à coletivização. É completamente impossível fornecer números precisos, pois não há fontes seguras. Sabemos que em 1933 existiam, a partir de 1929, cerca de 850000 kulaks (ou julgados como tal) deportados, mas é quase o único número preciso que possuímos. Sabemos igualmente que vários grandes trabalhos foram executados pela GPU a partir de 1930.” (ELLENSTEIN, 1976, p.102).

No início da década de 30, a influência de Trotsky, tanto na URSS como internacionalmente, começava a preocupar Stalin, provavelmente mais do que quando Trotsky ainda se achava na URSS. Pavel Sudoplátov, agente de segurança que executou ou organizou diversas missões sob ordens diretas de Stalin (inclusive o próprio assassinato de Trotsky), lembrou-se posteriormente: "Desde o exílio, seus esforços para cindir e logo controlar o movimento comunista mundial estavam prejudicando Stalin e a União Soviética. O desafio de Trotsky a Stalin confundiu o movimento comunista e debilitou nossa posição na Europa ocidental e na Alemanha durante os anos trinta.” (P. e A. SUDOPLÁTOV, 1994, p. 105).

No plano interno, a repressão massiva e a repressão seletiva contra os oposicionistas coexistem já desde 1930 (300 oposicionistas teriam sido detidos só em Moscou durante os primeiros meses desse ano). A Oposição de Esquerda, derrotada em 1927, parece protagonizar uma contra-ofensiva: "Em que pesem as fanfarronadas dos chefes do aparelho, a Oposição vive, trabalha e continuará a fazê-lo. Basta percorrer os jornais soviéticos para convencer-se de que não existe reunião de célula ou conferência do partido sem que oposicionistas ou semi-oposicionistas tomem a palavra. A luta do aparelho contra a Oposição de Esquerda é levada adiante só através da repressão. Na véspera do congresso [do PCUS] a repressão agravou-se terrivelmente. O monolitismo podre da cúpula é garantido pela força, as detenções, o exílio" (MARKIN, agosto 1930).

A essa informação, fornecida pelo órgão oposicionista de esquerda da época, caberia acrescentar as conclusões de estudos históricos mais recentes: a atividade da Oposição de Esquerda foi muito mais importante do que se supunha, na década de 30: na clandestinidade continuou a atrair pessoas que tinham se oposto antes a ela e o terror de 1936 (que vitimou um milhão dos dois milhões de membros que o PCUS possuia em finais da década de 20) seria basicamente uma resposta de Stalin ao grande movimento de protesto social, e à oposição que crescia dentro do próprio partido (ROGOVIN, 1998).

A oposição "de Riutin", surgida no próprio aparelho dirigente, em 1932, vincula-se sem dúvida a esse estado de coisas. Seu chefe, o próprio Riutin, escreveu um programa de 200 páginas e o fez difundir 
secretamente. Ali reivindicava, entre outras coisas, uma diminuição do ritmo da industrialização e da coletivização, a destituição de Stalin, apresentado como o "espírito mau" da revolução, comparável com os piores déspotas da história. Antes da condenação de Riutin, Stalin queria que fosse executado. Como Riutin pertencia à direção da organização moscovita do partido, era previsto que o Politburo do PCUS se pronunciasse. Stalin não obteve a maioria. Kirov e Ordjonikidzé recusaramlhe apoio. Desde a Revolução de Outubro, um dispositivo estabelecia que a pena de morte não poderia aplicar-se a nenhum membro do PCUS. Riutin e seu grupo foram condenados a penas de prisão. Para Stalin, isto representou uma derrota inexplicável (BUBERNEUMANN, 1975, 425). Das 200 páginas da "plataforma de Riutin”, 50 eram consagradas à descrição da personalidade de Stalin, caracterizada pela ambição pessoal e a sede de vingança. Ela recolheu numerosas assinaturas, entre elas as de antigos partidários de Bukhárin (Cf. BOUKHARINA, 1989, pp. 275-6).

\section{A crise do stalinismo}

Não é de surpreender que, neste quadro político, crescesse a figura "conciliadora" do chefe do partido em Leningrado, Kirov, o mais votado para o CC (Comitê Central) eleito no XVII Congresso do PCUS, em 1934 (eleição na qual Stalin chegou em último, com 270 votos contrários). As palavras do informe de Stalin para esse congresso soaram mais como expressão de desejos, ou como ameaça, do que como constatação objetiva: "Se no XV Congresso, de 1927, era necessário ainda demonstrar a correção da linha do partido e combater certos grupos anti-leninistas; se no XVI Congresso, de 1930, foi necessário dar o golpe de graça aos últimos partidários desses grupos, não há nada mais a ser demonstrardo neste Congresso, nem grupos a serem derrotados. Todo mundo compreende que a linha do partido venceu. Os debates do Congresso demonstraram a completa unidade dos dirigentes em todas as questões da política do partido. Não foi feita nenhuma objeção ao Informe" (STALIN, 1934). Stalin, então, renunciou a fazer o tradicional discurso de encerramento.

Nos anos posteriores, os delegados do Congresso, autores de tal façanha seriam recompensados por Stalin, de um modo que fica claro no famoso Informe Secreto de Kruschev ao XX Congresso do PCUS, de 1956, o qual revelou que dos 139 membros do CC do partido eleitos no XVII Congresso, 98 pessoas, ou seja, $70 \%$, foram detidas e fuziladas (a maioria em 1937-38...) Esta mesma sorte sofreram não só os membros do CC, mas também a maioria dos delegados do XVII Congresso do partido. Dos 1950 delegados com voz deliberativa ou consultiva, 1108, ou seja, mais da metade, foram detidos sob a acusação de crimes contra-revolucionários. A quase totalidade deles foi executada.

No quadro da crise de 1932-34 se situa o nebuloso episódio da entrevista, em Paris, entre um "membro do CC do PCUS, enviado de Kirov", e Leon Sedov, filho e mão-direita de Trotsky, na qual Kirov, por pessoa interposta, teria deixado entrever sua vontade de reintegrar todos os oposicionistas no partido, incluídos Trotsky e os trotskistas ${ }^{7}$. Teria sido o assassinato de Kirov, em dezembro de 1934, uma ação destinada tanto a evitar uma aliança entre o setor "conciliador" do aparelho (Kirov) e a oposição (Trotsky), contra Stalin, ao mesmo tempo que a fornecer o álibi do "grande terror" stalinista dos anos seguintes? A explicação parece demasiado perfeita, e não existem indícios conclusivos para aceitá-la completamente. Em qualquer hipótese, sabe-se também que, em que pese seu "recuo" no aparelho, em 1934,

\footnotetext{
7 Joubert, 1984. Nos escritos posteriores de Trotsky, porém, não existe nenhum indício nesse sentido, e Kirov é tratado como um simples burocrata, cujo assassinato foi usado por Stalin como pretexto para o terror da segunda metade da década de 30 .
} 
Stalin conseguiu situar seus "homens" (Ekhov, Kaganovitch, Malenkov) em postos-chave do aparelho de segurança (NKVD), e parece ter agido seguindo o critério de que qualquer retrocesso político era aceitável, conquanto ele próprio conservasse e aumentasse o seu controle desse aparelho (cujo poder e projeção cresceriam de modo espetacular nos anos imediatamente sucessivos).

Na década de 30, a possibilidade de uma crise política que levasse Trotsky de volta ao poder era vista, segundo Nicholas Mosley, como uma possibilidade real pelos estadistas ocidentais. Stalin, em troca, possuía, em relação aos seus aliados "conciliadores", maior trajetória e conhecimento do aparelho partidário e, com certeza, maior experiência política. Desde inícios da década de 30, já existiam tentativas da polícia política russa de se infiltrar na "fração internacional" trotskista: "Onde se encontra o limite entre um 'agente' e um militante que não o é, formalmente, mas que cede às pressões da GPU? Em 1932, o caso de Pavel Okhun, chamado de Mill ou J. Obin, secretário administrativo do secretariado internacional da Oposição de Esquerda, parece pertencer à última opção. Esse judeu ucraniano, vindo da Palestina para a Bélgica, tinha se unido neste país à Oposição de Esquerda, onde assumiu, devido às necessidades da correspondência em russo com Trotsky [aquela responsabilidade]" (BROUÉ, 1980 (1), 37). Em 1932, "Mill" voltou à URSS.

$\mathrm{Na}$ mesma época, registra-se a infiltração de "Senin", constatada só na década de 50: Abraham Sobolevicus ou Sobolevitch era filho de um industrial lituano, que possuia fábrica em Leipzig. Com seu irmão Ruvin (Roman Well) organizou uma oposição comunista que se juntou à Oposição de Esquerda alemã. Em 1936, Victor Serge, resgatado da prisão na URSS, transmitiu os rumores que lá existiam: "Senin" era agente da GPU. Nos anos 50, ele foi detido nos EUA, sob um novo codinome (Jack Soblen), ficando comprovada não só sua condição de agente dos ser- viços secretos da URSS, como o trabalho de informação que tinha realizado nas fileiras trotskistas na década de 30, fato que Trotsky e Sedov ignoravam.

\section{Trotsky e a crise mundial}

De acordo com testemunhas, Stalin lia regularmente e colecionava o Biulleten Opositsii, editado por Leon Sedov na Alemanha e, depois da ascensão de Hitler, em Paris: Stalin estava impressionado pela quantidade e qualidade das informações do órgão oposicionista (o que provavelmente aguçou a sua mania persecutória), assim como pelas suas análises políticas. No dia 20 de fevereiro de 1932, quando Trotsky ainda se encontrava na ilha de Prinkipo, Stalin o privou da nacionalidade soviética, por decreto especial. A importância do fato consiste no seguinte: daquele dia em diante, qualquer russo que entrasse em contato com Trotsky se tornava responsável por manter relações não apenas com a oposição interna, mas também com um traidor estrangeiro, ou melhor, para usar as palavras do próprio Stalin, "com o líder da vanguarda da contra-revolução mundial".

A influência internacional de Trotsky, sobretudo no interior da Internacional Comunista, só cresceu com a vitória de Hitler (que, diga-se de passagem, destruiu o partido comunista mais numeroso do Ocidente) pois, como notou Joseph Gorgerinski, Trotsky foi o primeiro - e, na época, o único - que procurou prevenir os operários alemães e o Comintern contra Hitler, incitando-os a formarem a tempo uma frente única com os socialistas para se defenderem: "Foram palavras jogadas ao vento. Naquele tempo, ninguém havia previsto que Hitler iria instaurar um regime totalitário. Todos o julgaram apenas mais um político ambicioso que almejava criar a seu redor um partido reacionário qualquer. Stalin afirmou que 'o fascismo e a social-democracia são irmãos gêmeos'. E Trotsky: 'Trabalhadores alemães, se Hitler subir ao poder, não 
haverá mais a mínima esperança para vós'. E previu tudo, tudo o que aconteceu a seguir..."

O desenvolvimento da crise revolucionária na Espanha, a partir de 1931, parece ter sido outro elemento decisivo no julgamento de Stalin. Segundo Lilly Marcou, "se a decisão de matar Trotsky foi expressa em 1939, na mente de Stalin ela começou a se gestar a partir de 1931, como testemunha um documento inédito dos arquivos daquele período. Em uma carta postal enviada ao Politburo, Trotsky aconselhava aos dirigentes soviéticos não se misturarem nas questões internas dos comunistas espanhóis, ou seja, "não lhes impor uma cisão vinda do exterior'. Furioso porque Trotsky ousava ainda dizer qual devia ser a conduta do partido, Stalin escreveu imediatamente: 'Penso que Trotsky, esse despudorado falastrão menchevique, deveria ser eliminado. Assim aprenderá a ficar no seu lugar"' (MARCOU, 1996, p. 132). A matriz de todo pensamento burocrático (quem tem ou não o direito de falar) está perfeitamente retratada nesse episódio.

Para Pierre Broué, as tentativas stalinistas de assassinar Trotsky são anteriores à sua partida para o México, em 1937: “[Elas] estiveram sempre nas inquietudes de seus camaradas. No primeiro período de seu exílio, duas tentativas merecem atenção, as duas vindas de 'brancos' manipulados pela GPU: a do grupo Turkul e a de Larionov. Nunca, pelo que se sabe, conseguiram localizar seu alvo. Mas o grupo principal [da GPU] de Paris aparece em 1935, o grupo de Efron, que seguiu Sedov, preparou seu seqüestro em Antibes, assassinou Ignace Reiss, e tentou envenenar a mulher e o filho deste. Esse grupo tinha também Trotsky na sua mira" (BROUÉ, 1988, p. 925). Os "brancos" eram o bando contra-revolucionário da guerra civil de 1918-21, que tinha todos os motivos para odiar Trotsky, chefe militar dos seus vencedores "vermelhos".

Gérard Rosenthal, advogado de Trotsky na França e ex-poeta surrealista, vinculado a André Breton, confirma Broué com diferença de alguns meses: "No início do verão de 1936, uma rede de espionagem foi constituída por Serge Efrom, compreendendo também Marcel Rollin (Smirenski), o falso fotógrafo Louis Ducomet ('Bob') e François Rossi, ou seja, Roland Abbiate, com mais dois ou três comparsas não identificados. Essa rede estava dotada de uma mensalidade regular" (Rosenthal, 1075, 227). Efrom (ou Efron) era casado com a poetisa russa Marina Tsévátieva: o ponto comum entre seu grupo e o "grupo Turkul" era a presença em ambos de exilados russos "brancos" (inclusive ex-oficiais do general czarista Wrangel) e membros da máfia européia (como Abbiate). Como o revelaram diversos affaires recentemente desvendados, o serviço secreto soviético não vacilava em recrutar nos mais diversos meios (inclusive os criminosos) e preferia agir através de pessoas interpostas, de preferência estrangeiros ${ }^{8}$.

\section{O terror desenfreado}

Recentemente, o ex-agente Pavel Sudoplátov, se contrapôs, nas suas memórias, à interpretação de que o assassinato de Kirov, que esteve na origem dos "Processos de Moscou", tivesse sido preparado entre bastidores pelo próprio Stalin. Para Sudoplátov tratou-se apenas de um "crime passional" executado pelo marido da amante de Kirov, o estudante Nikoláiev: "Não há provas de que Stalin ordenou o assassinato de Kirov para eliminá-lo como rival no poder; Stalin, ao ficar sabendo de sua morte, viu a oportunidade e soube

\footnotetext{
${ }^{8}$ Vide, por exemplo, o famoso episódio dos "cinco de Cambridge" (Kim Philby, Guy Burgess, Donald McLean, Anthony Blunt e John Cairncross), agentes duplos na inteligência britânica, recrutados quando estudantes na Universidade de Cambridge. Durante longo tempo se supôs que fossem apenas três, excluindo, além de Cairncross, Anthony Blunt, curador das jóias e coleções de arte da coroa inglesa: o impacto que a descoberta dessa rede provocou na opinião pública deveu-se tanto ao seu caráter espetacular como à origem social elevada dos seus membros.
} 
aproveitá-la. Ele decidiu inventar uma grande conspiração contra Kirov ou ele mesmo; explorou aquela situação para liquidar a todos os que ele considerava como rivais ou oponentes desleais, coisa que não podia tolerar" (P. e A. SUDOPLÁTOV, 1994, p. 89)9 . Trotsky, na época, denunciou de imediato a "mão de Stalin" por trás do assassinato, e previu as suas imensas consequiências políticas (no que o desenvolvimento ulterior dos fatos lhe deu razão). Se provas materiais nunca foram produzidas, reconstruções históricas minuciosas - como a do historiador soviético Medvedev (Cf. MEDVEDEV, 1972) - tendem a justificar a interpretação de Trotsky, para quem o crime e seu executor tinham sido, no mínimo, manipulados pela GPU-NKVD.

$\mathrm{O}$ assassinato de Kirov foi usado por Stalin como prova da existência de um vasto complô com vistas a assassinar todos os dirigentes soviéticos, complô supostamente chefiado por Trotsky. Os três "processos" subseqüentes, que se estenderam de 1936 a 1938, abalaram a opinião pública mundial, e foram acompanhados de uma repressão política em massa (Vadim Rogovin menciona 4 milhões de detidos e 800 mil fuzilados) sem precedentes na história moderna. Stalin não exagerava ao dizer, na época, ter chegado a hora de usar "métodos de guerra civil" contra a oposição interna. O mundo assistiu consternado às "confissões" de boa parte dos dirigentes da revolução de 1917.

\footnotetext{
${ }^{9}$ Está claro que a de Sudoplátov é também uma interpretação, que merece tanto crédito quanto a capacidade de raciocínio político exposta pelo autor em seu livro que, sem deixar de ser uma fonte importante de dados, é também uma enumeração quase rotineira de assassinatos, alguns cometidos de modo atroz, justificados por Sudoplátov pela sua "ingenuidade", explicação que, além de possuir limites precisos, não tem quase qualquer valor ou conteúdo histórico-políticos. A "ingenuidade”, nestas questões, é geralmente um álibi, não uma explicação: Sudoplátov tende, em geral, a negar a implicação da NKVD em qualquer crime em que aquela não tenha sido já provada.
}

Kamenev dizia: "Estamos aqui sentados lado a lado com os agentes de departamentos da polícia secreta estrangeira... Servimos ao fascismo, organizamos a contra-revolução contra o socialismo. Este foi o caminho que tomamos e este é o abismo da desprezível traição em que caímos." E Zinoviev: "Sou culpado de ter sido o organizador, secundando apenas a Trotsky no bloco trotskista-zinovievista, da proposição visando assassinar Stalin, Voroshilov e outros líderes... Fizemos uma aliança com Trotsky. Meu bolchevismo distorcido acabou se transformando em anti-bolchevismo e através do trotskismo chegou ao fascismo. O trotskismo é uma variação do fascismo, e o zinovievismo uma variação do trotskismo". E Vishinski, o promotor público, gritava: "Junto a minha voz irada e indignada ao troar das vozes de milhões... Exijo que esses cães danados sejam fuzilados, todos eles!" (Cf. People's Commissariat of Justice of the URSS, 1938). Vishinski, depois da guerra, iria tornar-se Ministro do Exterior da Rússia e seu representante junto às Nações Unidas.

Nesse mês de agosto de 1936, no centro do primeiro "processo", o "dos 16" (que foram todos fuzilados), Trotsky era denunciado como a alma do "bloco terrorista", e o trotskismo, como uma agência da Gestapo e do fascismo, no mesmo momento em que o CC do PC italiano propunha uma aliança "aos nossos irmãos fascistas", sobre a base do programa (fascista) de 1919, e em que Stalin sondava secretamente as possibilidades de um acordo com Hitler, que se concretizaria três anos depois. A imprensa dos PCs, e até a "democrática" (incluida a Liga dos Direitos Humanos da França) se somavam em todos os países à campanha "contra o trotskismo", e em geral contra qualquer um que não aderisse à recentemente aprovada linha da "Frente Popular". No segundo processo, em janeiro de 1937, em plena guerra civil espanhola e governo da Frente Popular na França, "os 18” (Radek, Serebriakov, Piatakov, Muralov, Drobnis, Sokolnikov, e outros) foram acusados e condenados por "ter cons- 
tituído um centro de reserva trotskista (!)", executando sabotagens e envenenamentos em massa, por conta da Gestapo e do Mikado...

As acusações lidas pelo procurador pareciam constituir o produto de uma imaginação doente: a investigação prévia teria provado "que, desde 1932 até 1936, se havia organizado em Moscou um centro unificado trotskista-zinovievista, com o propósito de perpetrar toda uma série de atos terroristas contra os chefes do PCUS e do governo soviético, com vistas à tomada do poder... Que o centro unificado trotskista-zinovievista havia organizado muitos grupos terroristas e adotado um certo número de medidas para proceder ao assassinato dos camaradas Stalin, Vorochilov, Jdanov, Kaganovitch, Kirov, Kossior, Ordjonikidzé e Postychev... que um dos grupos terroristas, sob as ordens diretas de Zinoviev e Leon Trotsky, e sob a direção imediata do acusado Bakaiev, havia perpetrado em 01 de dezembro de 1934 o assassinato do camarada S. M. Kirov". No seu veredicto principal, a Corte Suprema da URSS concluía que: "os inimigos do povo, Trotsky, Lev Davidovitch e seu filho Sedov, Lev Ivovitch, expulsos da URSS em 1929 e privados da nacionalidade soviética por decisão do Comitê Executivo Central da URSS, em caso de ser encontrados em território russo devem ser imediatamente presos e postos à disposição do Tribunal Militar da Corte Suprema da URSS" (Cf. People's Commissariat of Justice of the URSS, 1938).

\section{Vítimas e cúmplices}

No que respeita ao "apoio popular" aos processos, basta citar o testemunho de Margareth BuberNeumann, esposa do dirigente comunista alemão Heinz Neumann, então em Moscou: "A 23 de janeiro de 1937 - naquela mesma manhã havia começado o segundo processo de Moscou - Neumann e eu assistimos à manifestação do povo soviético, tão 'odiado' pelos acusados. Para dizer a verdade, esta manifestação não tinha nada de espontânea, foi organizada pelo governo. Os operários haviam sido trazidos diretamente das fábricas ao local da reunião. Assistir a ela era obrigatório. Também os empregados e colaboradores das 'Edições dos Trabalhadores Estrangeiros' deviam estar presentes. Uma numerosa multidão se amontoava nessa ingrata jornada invernal. Não se escutava grito algum. Os homens estavam em silêncio, de pé sobre a neve; as bandeiras e letreiros que levavam mostravam consignas espetaculares: 'Abatam-nos como a cães raivosos!'... 'Morte aos traidores fascistas!' Sobre um cartaz vi a imagem de um punho gigantesco armado de pregos, acompanhado por esta inscrição: 'Viva a NKVD, punho encouraçado da revolução!'” (BUBER-NEUMANN, 1975, 431).

No exterior, quase todos os partidos comunistas do mundo organizaram, na primavera e no verão, uma série de comícios e manifestações para apoiar o fuzilamento de Bukharin, Rykov, e outros. Tomando a palavra numa assembléia operária em Paris, em 3 de junho de 1938, Thorez, líder do Partido Comunista Francês, afirmou, por exemplo: "A justiça da União Soviética prestou inestimável serviço à causa da paz, golpeando impiedosamente os traidores trotskistasbukharinistas, esses assassinos e agentes da Gestapo, elementos da 'quinta coluna', cagoulards que tiveram alguns a chorar por eles na Inglaterra, mas que na realidade foram punidos com a necessária severidade". Na primavera de 1938, um "numeroso grupo de comunistas franceses" enviou carta a Ekhov, chefe da NKVD, onde se lia: "A sua firmeza e a sua vontade indomável levaram ao desmascaramento dos infames agentes do fascismo [...] asseguramos-lhe a nossa plena confiança na justiça popular, que puniu os traidores como eles mereciam."

Nos processos de 1937 e 1938 se ampliaram as acusações contra Trotsky e Sedov. No terceiro "processo" foram acusados e condenados Bukharin, Rykov, Rakovski (principal dirigente da Oposição de Esquerda na URSS, e posteriormente nos "campos" siberianos, até "capitular" em 1931) e até o ex-chefe 
da GPU, Iagoda. No ano anterior, um processo a portas fechadas tinha decapitado o Exército Vermelho, incluído seu oficial principal, o marechal Tukhachevski: no total, foram fuzilados mais oficiais do que foram perdidos em qualquer guerra, incluídos praticamente todos os chefes militares da guerra civil.

Um processo em separado acaba com os comunistas da Georgia que, em 1922, fizeram apelo a Lenin contra a "russificação" staliniana (Mdivani e Okudjava). Outro, ainda, "depura" a diplomacia (Karakhan) e o secretariado executivo dos soviets (Enukidzé). A repressão se abateu sobre centenas de milhares de membros do PCUS, que eram, no entanto, fiéis stalinistas. Stalin assinava listas de condenações que continham, às vezes, milhares de nomes. Foram "depurados" os PCs da Ucrânia e da Bielorrússia, as Juventudes Comunistas (Komsomol). O sindicalista e delegado da IC na China, Lominadzé, se suicidou. Outros foram fuzilados a portas fechadas, irredutíveis ou inapresentáveis para um processo público: Préobrazhenski, Slepkov, Riutin, Smilga, o general Dimitri Schmidt, Gaven (ex-delegado de Trotsky), todo o comando político do Exército Vermelho (Antonov-Ovseenko, Bubnov, Gamarnik), a velha direção da IC residente em Moscou (Piatniski, Béla Kun, dezenas de comunistas alemães, o suíço Fritz Platten, companheiro e amigo de Lenin). Direções inteiras dos PCs estrangeiros foram convocadas a Moscou e executadas (os PCs da Iugoslávia, excluído Tito, da Polônia...). A máquina de executar se precipitou também sobre juristas, historiadores, pedagogos, filósofos, físicos, matemáticos, biólogos, cientistas e artistas em geral: o diretor teatral Meyerhold foi executado após ser obrigado a beber a própria urina, o romancista Isaac Babel, autor da Cavalaria Vermelha, romance-símbolo da guerra civil de 1918-1921, também foi executado...

No mundo inteiro, a intelectualidade de esquerda e os "companheiros de estrada" dos PCs sofreram um abalo profundo. Daí a enorme importância das declarações feitas, no meio dos processos, pelo romancista André Malraux, símbolo mundial da "intelectua- lidade engajada", e amigo pessoal de Trotsky: "Trotsky é uma força moral no mundo, mas Stalin deu dignidade à humanidade $\mathrm{e}$, da mesma maneira que a Inquisição não atingiu a dignidade fundamental do cristianismo, os processos de Moscou não diminuíram a dignidade fundamental do comunismo" (Cf. CATE, 1995; e FREITAS, 1994). Trotsky, indignado, rompeu relações com Malraux...

A quantidade e, por assim dizer, a "qualidade" das mortes, só admitiam comparações com a monstruosidade delirante das acusações. A admissão passiva das mesmas pelos governos e a intelligentsia ocidentais constituiu, para Victor Serge, a "falência da consciência moderna"; isto inclusive no país em que essa consciência tinha sido galvanizada pelo "caso Dreyfuss", cujo eco ainda ressoava em todos os discursos políticos: "Eu lia no Pravda as resenhas truncadas dos processos. Apontava centenas de fatos inverossímeis, contrasentidos, grossas deformações, afirmações insensatas. Mas o delírio era também um dilúvio. Apenas tinha concluído de levantar um monte de imposturas, um monte maior chegava, varrendo o trabalho da véspera. Isto ultrapassava todos os limites. O Intelligence Service misturava-se à Gestapo, ao Japão, os acidentes ferroviários viravam crimes políticos, a grande fome resultante da coletivização tinha sido organizada pelos trotskistas (todos presos na época!), uma multidão de acusados a espera de processo desaparecia nas trevas, milhares de execuções eram realizadas sem nenhum processo, e havia nos países civilizados juristas instruídos e 'avançados', que consideravam esses procedimentos normais e dignos de crédito. Tudo virava uma lamentável falência da consciência moderna. Na Liga Francesa dos Direitos Humanos havia juristas dessa espécie: ela se dividia entre uma maioria contrária a qualquer investigação a respeito, e uma minoria desencorajada, que se retirava. $\mathrm{O}$ argumento mais comum era: 'Rússia é a nossa aliada'...” (SERGE, 1978, 350) (grifo nosso). 


\section{A consciência humana}

Certamente, houve vozes que protestaram, muito minoritárias, que merecem ser citadas. Em primeiro lugar, o esforço do próprio Victor Serge, que constituiu em Paris - junto com o surrealista André Breton, o pacifista Félicien Challaye, o "poeta proletário" Marcel Martinet, escritores socialistas como Magdeleine Paz e André Philip, outros como Henry Poulleille e Jean Galtier-Boissière, militantes operários como Pierre Monatte e Alfred Rosmer, militantes de esquerda (Georges Pioch, Maurice Wullens, Emery), historiadores como Georges Michon e Maurice Dommanget - um "Comitê pela Investigação dos Processos de Moscou e pela Liberdade de Opinião na Revolução".

Leon Sedov tentou, em vão, constituir uma comissão independente na Suíça, com ajuda de um advogado de Basiléia. A mais importante foi a constituição de uma comissão nos Estados Unidos, que colheu o depoimento de Trotsky no México (depois de tentar em vão obter um visto para que aquele pudesse fazê-lo nos EUA). Entre os membros, apenas um amigo de Trotsky: Alfred Rosmer. Os demais eram "esquerdistas" de diversas tendências, sindicalistas, radicais, anarquistas, comunistas, na maioria militantes do campo politicamente adversário de Trotsky. O presidente foi o ilustre filósofo e educador norte-americano John Dewey, mundialmente conhecido. Após longos meses de trabalho extenuante e meticuloso, cada ítem e cada acontecimento histórico haviam sido investigados e analisados, até se eliminarem todas as sombras de dúvida. E o veredicto da comissão Dewey foi de total e absoluta inocência dos acusados: "Com base em todas as provas em nosso poder afirmamos que os processos realizados em Moscou em agosto de 1936 e janeiro de 1937 não passam de uma fraude... Declaramos inocentes Lev Davidovitch Trotsky e Leon Sedov". Ao lado de John Dewey, Suzanne La Follette e Otto Rühle tiveram importante papel nessa comissão verdadeiramente internacional, que teve repercussão profunda na intelectualidade e na opinião pública dos Estados Unidos (Cf. ROCHE, 1990; e WALD, 1979) ${ }^{10}$.

Meio século depois, alguns raros sobreviventes dos "Processos de Moscou" deixaram clara a armação existente por trás dos mesmos. Foi o caso de Vladimir Astrov, um velho bolchevique, que tinha se incorporado ao partido antes da Revolução de Outubro, e foi um importante jornalista e historiador que pertenceu ao círculo de Bukharin durante a década de 20. Preso pela primeira vez em 1933, se converteu em seksot, colaborador secreto da NKVD; confrontado com Bukharin, afirmou que a oposição direitista havia preconizado o terrorismo em geral e o assassinato de Stalin em particular. Quando escreveu a respeito em 1989, aos noventa anos, afirmou que considerava o Astrov de 1932 um ser humano distinto, pois desde então muitas coisas haviam mudado. Ele considerava que os investigadores eram representantes do partido e havia acatado suas exigências, o que havia terminado na confrontação com Bukharin; depois, caso único, saiu da prisão.

A grande defesa política de Trotsky, porém, foi realizada pelo seu filho, Leon Sedov, o qual não só teve papel decisivo na criação das "comissões" na França e nos Estados Unidos (e no frustrado "contraprocesso" suíço), como também publicou, em finais de 1936, o Livro Vermelho dos Processos de Moscou, onde desmontou a falsidade de facto e jurídica dos processos, como analisou a lógica política existente por trás deles: "Quando Trotsky estava ainda na

\footnotetext{
${ }^{10}$ Em Moscou, a Comissão Dewey foi combatida através da detenção de um certo Donald L. Robinson, americano, apresentado como "espião trotskista" vinculado ao Japão, aos trotskistas dos EUA e à própria Comissão. A reação nos EUA, em especial a investigação do conhecido jornalista Herbert Solow, demonstraram rapidamente que se tratava de uma montagem, que visava preparar o terreno para um processo contra a Comissão. O tal "Robinson" nunca foi identificado.
} 
URSS, nas mãos da camarilha termidoriana, Stalin tinha pensado que uma operação minuciosa finalizada no exílio era o melhor meio de se livrar de um bolchevique irredutível. Enganou-se, e não é necessário ser muito perspicaz para perceber o quanto esse erro o angustia. Hoje, diante da oposição renascida e em crescimento, faz fuzilar friamente bolcheviques, velhos dirigentes do partido e da IC, heróis da guerra civil. Stalin quer a cabeça de Trotsky, esse é seu objetivo principal. Irá até o fim para conseguí-lo. Qualquer ilusão contrária foi dissipada pelo Processo de Moscou. Stalin odéia Trotsky como representante vivo das idéias e tradições da Revolução de Outubro, que atrai tudo o que resta de revolucionário na URSS. Para ter a sua cabeça, Stalin se entregou às piores intrigas na Noruega, e prepara outras na Sociedade das Nações [onde a URSS tinha sido admitida a partrir de 1933, NDA], preparando o terreno para a extradição de Trotsky. É por isso que o governo soviético manifestou grande interesse pela colaboração policial internacional contra os terroristas, por ocasião do assassinato do rei da Iugoslávia” (SEDOV, 1981, p. 9 e 123).

\section{Perseguição e IV Internacional}

Para Trotsky, os "processos" e a repressão na União Soviética significaram o recrudescimento da sua perseguição. Expulso da França para a Noruega, aí será "internado", em 1936, pelo governo "socialista" (social-democrata) de Trygve Lie, não sem antes ter sua casa queimada e parte dos seus arquivos roubados por um grupo nazista norueguês. Trotsky viu na ação uma provável conivência com a GPU russa, conhecedor do modo de agir indireto do serviço de Stalin, suspeita que se confirma pelo comentário posterior do futuro chefe da Noruega ocupada por Hitler, Quisling (“Teria sido mais simples entregá-lo à embaixada russa. Provavelmente o teriam enviado a Moscou em uma urna...”). Trotsky enfrentava, na verdade, uma coalizão stalino-nazista com cobertura social-democrata: "Entre o ataque nazista e a saída de Trotsky da Noruega, a cumplicidade entre a URSS e a Alemanha nazista é visível nas tomadas públicas de posição de ambas e das organizações políticas a elas vinculadas. Ambas afirmam defender a Noruega e suas leis, contra um revolucionário sem fé nem lei para os nazistas, contra um contra-revolucionário terrorista para a URSS. Ambas estão de acordo nas acusações, nas injúrias e nas ameaças, e também na reivindicação da expulsão de Trotsky da Noruega, que colocaria a possibilidade de um seqüestro pela URSS, onde o esperava um assassinato judicial" (BROUÉ, 1988 , p. 839). Para os nazistas, cabe acrescentar, Trotsky é também um "judeu"; para os stalinistas, um "cosmopolita" (ou seja, um judeu...).

A obtenção do asilo no México deu a Trotsky o prazo suplementar que esperava da vida: "O desmoronamento das duas Internacionais trouxe um problema que nenhum dos seus chefes tem possibilidade de enfrentar. As particularidades de meu destino pessoal me colocaram diante desse problema, armado com uma séria experiência. Oferecer um método revolucionário à nova geração, por cima das cabeças dos chefes da II e III Internacionais, é uma tarefa que não tem, afora minha pessoa, homem nenhum que a possa cumprir (...) Preciso ainda de pelo menos cinco anos de trabalho ininterrupto para assegurar a transmissão desta herança", escreveu Trotsky em 1935 (TROTSKY, sdp, p. 53). A picareta do agente de Stalin esperou quase exatos cinco anos.

No trabalho de preparação da IV Internacional estiveram associados dirigentes bolcheviques (Preobrazhenski, primeiro secretário-geral do PCUS, Khristian Rakovsky, Muralov, Smilga), os chineses Chen Tu-Xiu e Pen Shu-Tze (primeiros secretário-geral e secretário de organização do PC chinês), os belgas Leon Lesoil e Abraham Leon, o holandês Henk Sneevliet (fundador do PC da Indonésia), o francês Alfred Rosmer (fundador do PCF e da Internacional Comunista), os italianos Pietro Tresso e Alfonso 
Leonetti (dirigentes do PCI), o vietnamita Ta Thu-Thau, dirigente da luta contra o colonialismo francês (Cf. HÉMERY, 1975), o catalão Andreu Nin (dirigente da IC), Pantelis Poliopoulos, secretário-geral do PC grego e, na América Latina, o senador comunista chileno Manuel Hidalgo, o cubano Sandálio Junco (primeiro grande dirigente operário negro), o dirigente gráfico brasileiro João da Costa Pimenta (fundador do PCB), o argentino Mateo Fossa (fundador da CGT), e outros.

Era a flor e a nata do movimento operário e revolucionário internacional, perseguida pelo fascismo e pelo stalinismo (metade dos nomeados morreu assassinada): o seu programa baseava-se na defesa da revolução proletária (abandonada pelas II e III Internacionais), retomava as linhas básicas dos quatro primeiros congressos da III Internacional (1918-1922) e analisava a nova situação criada pelo retrocesso da revolução soviética (surgimento da burocracia stalinista) propondo uma revolução política na URSS, que devia completar a revolução social de outubro de 1917 , assim como as revoluções de 1830 e 1848 tinham completado a revolução social de 1789 na França. Mas, ao contrário dessa revolução burguesa (nacional), a revolução política na URSS era um aspecto da revolução proletária internacional. Trotsky pensava que a revolução mundial daria uma nova vitalidade ao proletariado soviético, capaz de libertá-lo.

A repressão contra Trotsky e seus partidários não se limitou à URSS, embora aí fosse especificamente forte. Em 1938, em carta a um procurador francês, ele denunciava: "Iagoda levou uma das minhas filhas a uma morte prematura, e a outra ao suicídio. Deteve meus dois genros, que desapareceram sem deixar rasto. A GPU deteve meu filho menor, Serguei, sob a acusação inacreditável de envenenar operários, depois do que ele desapareceu. Levou ao suicídio dois dos meus secretários, Glazman e Butov, que preferiram a morte a realizar declarações contra sua honra ditadas por Iagoda. Outros dois secretários russos, Poznansky e Sermuks, desapareceram na Sibéria. Ainda há pouco, a GPU sequestrou na Franca outro ex-secretário meu, Rudolph Klement. A polícia francesa o buscará, o encontrará? Eu duvido. A lista citada não compreende mais do que as pessoas mais próximas, não falo das milhares que morreram na URSS, nas mãos da GPU, sob a acusação de "trotskistas"' (TROTSKY, 1938).

Em julho de 1937 “desapareceu”, na Espanha, o jovem tcheco Erwin Wolf, ex-secretário de Trotsky e um dos principais organizadores da IV Internacional, provavelmente morto em setembro por Erno Gerö, futuro dirigente da "Hungria popular". Nesse ano a NKVD leva a sua atividade ao mundo inteiro, contra todos aqueles que Stalin designa como "trotskistas". Há uma longa lista de mortes que lhe são atribuídas na Espanha, através das suas agências locais, chamadas de tchekas. Sob a responsabilidade de russos como Orlov e Eitingon, de italianos como Vittorio Vidali $^{11}$, de alemães como Herz, de húngaros como Gerö, da ítalo-americana Tina Modotti, se sucedem sequüestros e mortes de adversários políticos de Stalin $^{12}$. Esta ação internacional expressava a transformação decisiva acontecida na URSS nesses anos,

\footnotetext{
${ }^{11}$ Depois da Segunda Guerra, Vidali foi deputado no parlamento italiano pelo PCI, passando boa parte do restante da sua vida se defendendo das acusações de assassinato de mlitantes das mais diversas tendências de esquerda, que choveram sobre ele.

${ }^{12}$ Sobre o papel de Tina Modotti, atriz, pintora, fotógrafa, na "segurança" staliniana na Espanha, e no México, existe uma vasta documentação recolhida por Pierre Broué nos Cahiers Léon Trotsky de 1978-1980, que não nega o seu talento artístico. Numa biografia que não raro descamba para a hagiografia, Barckhausen-Canale (1989) descarta esse aspecto da sua biografada, e despreza, em, breves linhas, as alegações dos "trotskistas", aos quais se refere com um linguajar tipicamente staliniano. Na guerra civil espanhola, Modotti foi adjunta no serviço de contra-espionagem das Brigadas Internacionais, em Albacete, cargo de impossível acesso se não se pertencesse à GPU. Margaret Hooks $(1997,262)$ confirma que, na Espanha e no México, "Tina estava envolvida em algum tipo de trabalho clandestino", sem procurar ir além dessa constatação.
} 
assim resumida por Martin Malia: "Entre 1936 e 1938, num fenômeno sem precedentes na história, a direção do partido fez um gigantesco golpe de estado: aproximadamente $80 \%$ dos quadros do partido foram substituídos, foi levantado um novo partido, com Stalin na cabeça, um novo conjunto de quadros na economia e na agricultura, no exército, etc." (MALIA, 1980, p. 219).

A Espanha revolucionária será o campo fundamental de ação da nova "polícia política internacional" de Stalin, como reconhece um dos seus principais quadros, de maneira curiosamente neutra: "De 1936 a 1939 houve na Espanha duas lutas de vida ou morte. Uma enfrentava as forças nacionalistas dirigidas por Francisco Franco, ajudado por Hitler, contra os republicanos, apoiados pelos comunistas. A outra era realizada pelos próprios comunistas entre si. Stalin, na URSS, e Trotsky, no exílio, abrigavam a esperança de serem os salvadores e fiadores dos leais à República, transformando-se assim na vanguarda da revolução comunista mundial. Os soviéticos enviavam para a Espanha nossos jovens e inexperientes agentes de espionagem, assim como nossos instrutores avançados. A Espanha foi uma escola magnífica para nossas operações futuras" (A. e P. SUDOPLÁTOV, 1994, p. 59).

O autor parece "esquecer" que os mortos dessa "guerra civil paralela" só se encontravam em um dos lados em disputa, e que a "escola de espionagem" se exercitou contra o restante da esquerda, não contra o fascismo franquista. Na verdade, a Espanha foi o cenário de uma luta política fundamental entre a revolução e a contra-revolução. Nas retaguardas republicanas, os partidos "democráticos" e seus aliados stalinistas realizaram uma verdadeira "guerra suja" contra os "comitês" que levantaram os trabalhadores espanhóis para defender sua revolução. Acredita-se que o brigadista brasileiro Alberto Besouchet tenha sido assassinado desse modo: "O PCB desconfiava que Besouchet fosse trotskista...Há dados que comprovam que os PCs francês e espanhol o investigaram e, provavelmente, o as- sassinaram por lutar em uma milícia trotskista" (BATTIBUGLI., 2000). A brutalidade da repressão no campo republicano levou, por exemplo, o escritor mexicano Octavio Paz, que visitou Espanha durante a guerra civil, a mudar sua posição de simpatia pelo Partido Comunista Mexicano: "Octavio e Elena [sua esposa] ficaram impactados pelas lutas partidistas existentes nas fileriras anti-franquistas...em contato com socialistas verdadeiramente independentes, pôde conhecer a fundo a crua realidade da retaguarda republicana...A posição de Octavio Paz diante do assassinato de Andreu Nin, dirigente do POUM, despertou a admiração e a estima para o POUM de jovens socialistas [mexicanos]" (COSTA-AMIC, 1994, p. 19 e 31).

Os "comissários" da GPU-NKVD foram os chefes dos "grupos de tarefa" que assassinaram milhares de revolucionários, anarquistas, poumistas e trotskistas, o que abriu, de fato, o caminho para a vitória de Franco. Foram estes homens, transformados em assassinos profissionais de revolucionários, os recrutados para assassinar Trotsky. Seu arquétipo era o italiano Vittorio Vidali, "comissário" do célebre "5 Regimento", e responsável pelo seqüestro, tortura e assassinato do dirigente do POUM, e expresidente da Internacional Sindical Vermelha, o catalão Andreu Nin. Fizeram também sua carreira dirigindo a repressão na Espanha homens como Palmiro Togliatti e Vittorio Codovilla, secretáriosgerais "vitalícios" dos PCs da Itália e Argentina. Ramón Mercader, que viria a ser o assassino de Trotsky, também "serviu" na Espanha.

O assassinato de Andreu Nin, amigo pessoal de Trotsky, revestiu-se de particular crueldade. Em 1937, no quadro da ofensiva contra o POUM, fora sequestrado por um comando da NKVD chefiado pelo "general Alexander Orlov" (do qual voltaremos a nos ocupar), que tentou arrancar-lhe em vão uma "confissão" de colaboração com o fascismo. De acordo com o ex-dirigente do PC espanhol, ex-ministro da República, Jesús Hernández, depois de interrogató- 
rios intermináveis, nos quais "Nin não capitulava", seus sequestradores "decidiram abandonar o método 'seco'. O sangue vivo, a pele rasgada, os músculos destroçados, poriam à prova a sua capacidade de resistência. Nin suportou a crueldade da tortura e a dor do tormento refinado. Depois de alguns dias seu corpo tinha virado uma massa informe de carne macerada" (Apud ALBA, 1975, 508). Para disfarçar sua morte, foi desastradamente fingido um "sequestro" por um comando da Gestapo alemã infiltrado...nas Brigadas Internacionais. O suposto "comando" nunca foi identificado, e o corpo de Nin nunca foi achado (atualmente, uma placa de bronze, nas Ramblas de Barcelona, lembra o último local onde Andreu Nin foi visto com vida).

\section{A caçada mundial}

A Espanha foi a verdadeira "prova de fogo" que treinou e "formou" esses homens. Ali também se forjaram os homens que entrariam na Europa do Leste com os tanques soviéticos para criar as "democracias populares", depois da Segunda Guerra: entre o sangrento esmagamento da insurreição operária de Barcelona e a brutal repressão dos levantamentos dos trabalhadores de Berlim, Budapeste e Praga nas décadas de 50 e 60 há um fio condutor através da história.

Segundo Siqueiros, o assassinato de Trotsky começou a ser preparado na Espanha: “Após Cárdenas ter dado asilo político a Trotsky, Siqueiros y Vidali foram a uma reunião do PCE, onde La Pasionaria [a dirigente comunista espanhola Dolores Ibarruri] praticamente esbofeteou os mexicanos em relação ao caso Trotsky. Com sua masculinidade revolucionaria desafiada, Siqueiros disse que ele e outros membros da sociedade Javier Mina de ex-combatentes, da qual Vidali era membro proeminente, se consideraram obrigados a levar a cabo o ataque e a destruir a chamada fortaleza de Trotsky em Coyoacán" (HOOKS, 1997, p. 263)
Em inícios de 1937 fracassou uma tentativa da GPUNKVD de seqüestrar Leon Sedov, em Mulhouse (França), destinada provavelmente a sentá-lo no banco dos acusados do segundo processo de Moscou (Cf. BROUÉ, 1983). No mesmo ano, segundo Pavel Sudoplátov, teria fracassado a primeira tentativa de eliminação de Trotsky, confiada por Stalin pessoalmente a um dos dirigentes do NKVD, Mikhail Spiegelglass (A. e P. SUDOPLÁTOV, 1994, p. 103). Mas em fevereiro de 1938, Leon Sedov, então com 32 anos, morreu misteriosamente depois de uma operação de apendicite em uma clínica parisiense de propriedade de um emigrado russo branco, provavelmente vinculado à NKVD.

As circunstâncias da morte, assim como o fato comprovado de que o principal colaborador de Sedov, o russo de origem polonesa Mordchka Zborowski, foi desmascarado em 1954, nos EUA (onde era professor universitário de antropologia) como agente da NKVD, sob o codinome «Mark» (na IV Internacional, seu codinome era «Etienne») -mas este fato foi ignorado por Trotsky enquanto viveu- levaram a pensar que Sedov fora assassinado pela NKVD. ${ }^{13}$ Isto nunca ficou completamente provado. Na sua biografia de Trotsky, Dmitri Volkogonov sustenta que Sedov foi assassinado pela NKVD, o que é negado por Sudoplátov, que afirma não ter encontrado provas disso no seu processo (nos arquivos da KGB russa), e que "ninguém foi condecorado ou reivindicou essa honraria", por esse fato (P. e A. SUDOPLÁTOV,

\footnotetext{
${ }^{13}$ Dois médicos franceses, fazendo uma "autópsia retroativa", chegaram à conclusão de que Sedov pôde, de fato, ter morrido de complicações pós-operatórias (Krivine e Kahn, março 1983). Gérard Rosenthal sustenta que os "agentes russos" encontraram certas facilidades para infiltrar-se no entourage de Trotsky e Sedov devido a que ambos "eram muito sensíveis ao clima em comum e ao universo compartilhado que teciam entre si os oriundos da Rússia, facilitando uma conivência privilegiada, na qual os ocidentais não acediam com facilidade" (ROSENTHAL, 1975, p. 262).
} 
1994, p. 121). Volkogonov, militar de alta patente (antes de morrer foi assessor militar de Boris Ieltsin) deve ter tido fortes razões para sustentar o contrário.

"Mark" ou "Etienne" já tinha despertado as suspeitas de Victor Serge e Pierre Naville, entre outros militantes, que se dirigiram a Trotsky nesse sentido. Mais ainda, em 1939, "Trotsky recebeu em Coyoacán uma estranha carta anônima. Seu autor afirmava ser um velho judeu apátrida refugiado nos EUA. Pretendia ter recebido de um alto chefe dos serviços secretos soviéticos, tránsfuga no Japão, a confidência dos brilhantes serviços de um cero Mark, cuja descrição coincidia com a pessoa de Étienne" (ROSENTHAL, 1975, p. 263). O "velho judeu apátrida" era nada menos que "Alexander Orlov" (codinome de L. L. Feldbine, de fato judeu, mas não apátrida nem velho), um dos principais agentes da NKVD (ou "espião da URSS", como se dizia nos meios ocidentais) no exterior, veterano não só da guerra civil espanhola, mas também da guerra civil de 1918-21, quando tinha servido no Exército Vermelho sob o comando de Trotsky.

Em 1938, o "general Orlov" tinha desertado, e "havia mandado uma carta pessoal a Stalin dos EUA, explicando sua deserção por sua iminente prisão a bordo de um barco soviético. A carta estabelecia que se Orlov descobrisse qualquer tentativa dos soviéticos de averiguar seu paradeiro ou indícios de ser vigiado, pediria a seu advogado que tornasse pública uma carta que ele havia depositado em um banco suíço, que continha informação secreta sobre falsificação de materiais para o Comitê Internacional para a Não-Intervenção na guerra civil espanhola. Orlov ameaçava também contar toda a verdade sobre o ouro espanhol, depositado secretamente em Moscou, e proporcionar as listas de embarque. Esta história teria significado um embaraço para o governo soviético e para os refugiados de guerra espanhóis no México, porque o apoio militar soviético à causa republicana era concedido supostamente em nome da solidariedade socialista” (A. e P. SUDOPLÁTOV, 1994, p. 78).
Nas suas memórias, Orlov afirma também ter tentado entrar em contato telefônico com Trotsky, para advertí-lo sobre a presença de Etienne-Zborowski (que ele chamava de "Mark") no seu entourage, e sobre o papel deste no roubo dos arquivos de Trotsky depositados na filial de Paris do Instituto de História Social de Amsterdã, onde ficariam aos cuidados do historiador menchevique David Dallin (casado com Lola Estrine, ou Lilia Ginzberg, ex-colaboradora direta de Leon Sedov em Paris). Na ocasião, Orlov não conseguiu passar do secretário de Trotsky (Jan Van Heijenoort), para o qual não quis se identificar. Quando a parte fechada dos arquivos de Trotsky na Harvard Library foi aberta, Pierre Broué descobriu uma cópia de uma carta de Trotsky (dirigida a quem?) a respeito de "Etienne" e da carta do "velho judeu", que desmente a versão de que Trotsky teria feito ouvidos surdos às suspeitas que pesavam sobre o excolaborador de Sedov: "É necessário seguí-lo de maneira discreta e eficiente. Me parece que devemos pôr no assunto a [Boris] Nicolaievski. Criar uma comissão de três: Rosmer, Gérard [Rosenthal] e Nicolaievski, agregando dois ou tres jovens para o seguimento, de modo individual e absolutamente secreto. Se a informação se revela verdadeira, garantir a possibilidade de denunciá-lo à polícia francesa pelo roubo dos arquivos, em condições que não possa fugir. Comunicar de imediato estas informações a Rosmer. O melhor seria através de [James P.] Cannon, se ainda está aí [Paris], ou de [Max] Schachtman, se ele for [a Paris]. Vocês encontrão os meios. Peço notificação de recepção" (BROUÉ, 1980b).

Aparentemente, nada foi feito, e "Etienne" só foi descoberto em 1954, nos EUA, pelo FBI, após confissão de "Soblen" (Sobolevicius), ele também exespião nas fileiras trotskistas. Pouco tempo antes, tinha se entrevistado com Gérard Rosenthal, enviando calorosas saudações "aos camaradas franceses". Nos EUA, Zborowski-“Etienne" só recebeu uma pena leve, por perjúrio nas suas declarações a respeito das 
atividades dos "irmãos Soblen": no interrogatório a que foi submetido, muito minucioso, quase nada lhe foi inquirido a respeito da sua longa relação com Sedov como agente da NKVD, nem a respeito da sua possível implicação na morte dele, assuntos que evidentemente pouco interessavam aos serviços secretos dos EUA (Cf. LEQUENNE, 1983). Zborowski"Etienne"-“Mark" morreu há uma década nos EUA, transformado em um anti-comunista declarado.

\section{Trotsky e a crise de NKVD}

Um aspecto fundamental a ser destacado é que os principais "desertores" do "sistema de segurança" internacional do aparelho stalinista, durante a década de 30, buscaram alguma forma de colaboração com Trotsky, com graus diversos de aproximação política. Na verdade, tratava-se de quadros em processo de ruptura política, muito mais que de "espiões russos passados para o Ocidente", como fomos acostumados a vê-los pela literatura e a mitologia do "mundo livre" no pós-guerra: eram os quadros da GPU-NKVD, e do aparelho clandestino da Internacional Comunista, recrutados durante a revolução russa e a guerra civil ${ }^{14}$. Já falamos de Alexander Orlov (codinome de Alexandr Nikolski) (Cf. ORLOV, 1953), célebre por ter recrutado e formado o "círculo de Cambridge" (Russell, Philby, MacLean, Burgess, Blunt e Cairncross), depois infiltrado no serviço secreto britânico ${ }^{15}$.

\footnotetext{
${ }^{14}$ A crise política dos aparelhos de segurança da URSS durante os grandes expurgos é um aspecto negligenciado pela historiografia corrente, mais preocupada nos aspectos espetaculares da "espionagem" ou na elaboração de uma base historiográfica para o anti-comunismo. Cf., por exemplo: Dziak, 1988; Barron, 1985; Andrew e Gordievskij, 1996.

${ }^{15}$ Segundo pesquisas recentes, esse círculo teria inspirado o romance de Graham Greene, The Third Man, do qual foi tirado o filme homônimo, protagonizado por Orson Welles e Joseph Cotten.
}

Caberia também mencionar a Walter Krivitsky (codinome de Samuel Ginzburg) (Cf. KRIVITSKY, 1939), que rompido com a NKVD em 1937, esteve em contato direto com Leon Sedov e, depois, com Jan Frankel, trotskista americano, "com a consciência pesada, recusando dramaticamente julgar ou ser julgado, não querendo ser outra coisa que um soldado prestes a obedecer, incapaz de refletir ou de pensar por conta própria, propondo só ser útil a Trotsky lhe fazendo conhecer, através dele, um tipo de homem que Trotsky não conhecia. E Sedov, diante dele, lhe falando em nome de Outubro e da revolução mundial, reivindicando e exigindo-lhe uma declaração política condenatória do stalinismo, e chamando à defesa da URSS" (BROUÉ, 1983). E os trotskistas sabiam que Krivitsky e Orlov eram responsáveis pelo assassinato de vários de seus camaradas, principalmente na Espanha...

Durante o "grande terror", os expurgos atingiram também os aparelhos clandestinos e de segurança da URSS. Pavel Sudoplátov lembra disso à sua "ingênua" maneira: "Muitos de nossos amigos, gente em quem confiávamos completamente, haviam sido detidos sob acusação de traição. Supúnhamos que aquilo era o resultado da incompetência de Ekhov. Quero revelar aqui um fato importante que os livros dedicados à história da polícia política soviética passaram por cima. Antes de Ekhov assumir o comando da NKVD, não existia nenhum departamento especial para investigações internas. Isto queria dizer que o agente de enlace devia investigar pessoalmente qualquer delito cometido por seu pessoal. Ekhov criou o Departamento de Investigações Especiais dentro da NKVD [com esse objetivo]" (P. e A. SUDOPLÁTOV, 1994, p. 71). Sudoplátov aproveita para negar qualquer responsabilidade da NKVD na morte (assassinato) de Krivitsky, nos EUA, em 1941, aderindo à tese oficial de "suicídio".

Um outro membro do aparelho clandestino, depois lendário graças ao seu livro de memórias, Jan Valtin 
(codinome de Richard Krebs), talvez deva a sua vida ao contato com os trotskistas, pois se encontrava em situação extremamente difícil (procurado simultaneamente pela Gestapo hitleriana -Krebs era alemão-e a NKVD) no momento da sua ruptura: "Depois que tomou a sua decisão, Valtin foi para Anvers [porto na Bélgica] onde, segundo o agente da Gestapo 'König', um grupo trotskista, chefiado por certo Jiske, ajudouo a embarcar em um barco inglês destinado aos EUA, onde chegou em fevereiro de 1938" (BAYNAC, 1975, p. 708). O próprio chefe da espionagem soviética no ocidente durante a Segunda Guerra Mundial -a célebre "orquestra vermelha"-fez um reconhecimento, nas suas memórias, ao papel dos trotskistas, contra o stalinismo, na década de 30 (Cf. TREPPER, 1977).

Embora tenha sido principalmente um jornalista, cabe também mencionar o galês Burnett Bolloten, correspondente da UP na Espanha durante os primeiros anos da guerra civil. Instalado no México com uma enorme documentação espanhola, teve uma experiência com seus amigos de então, pois logo depois do atentado de 24 de maio de 1940 contra Trotsky, Vittorio Vidali lhe pediu para esconder Tina Modotti, procurada por esse atentado pela polícia. Passou então a analisar a sua documentação sob um ângulo novo, e a defender a revolução espanhola destruída pelo stalinismo. Em 1961, publicou uma das mais completas denúncias do papel do stalinismo na revolução e na guerra civil espanholas (BOLLOTEN, 1975).

O mais importante, porém, foi o "caso Ignace Reiss" (codinome, como já foi dito, do polonês Ignacy Poretski). Este, um dos mais importantes agentes da NKVD na Europa ocidental, rompeu com o stalinismo denunciando não só os seus crimes, mas também a sua base política, e aderindo explicitamente à IV Internacional: "O dia em que o socialismo internacional julgar os crimes cometidos no curso dos dez últimos anos está próximo. Nada será esquecido, nada será perdoado. A história é severa: 'o chefe genial, o pai dos povos, o sólido socialismo’ darão conta de seus atos: a derrota da revolução chinesa, o plebiscito vermelho, o esmagamento do proletariado alemão, o social-fascismo e a frente popular, as confidências ao senhor Howard, o idílio enternecido com Laval: todas elas histórias insólitas! Esse processo será público e com testemunhas, uma multidão de testemunhas, mortos e vivos: todos falarão uma vez mais, porém desta vez para dizer a verdade, toda a verdade. Comparecerão todos esses inocentes destruídos e caluniados, e o movimento operário internacional reabilitará a todos, a Kamenev, Mratchkovski, Smirnov, Muralov, Drobnis, Serebriakov, Mdivani, Okudjana, Rakovski e Andreu Nin, todos esses 'espiões e provocadores, todos esses agentes da Gestapo e sabotadores’! Para que a União Soviética e o movimento operário internacional em seu conjunto não sucumbam definitivamente sob os golpes da contra-revolução aberta e do fascismo, o movimento operário deve se desvincular de Stalin e do stalinismo"16.

Reiss anunciou a sua ruptura numa carta ao CC do PCUS de julho de 1937 (da qual extraímos os parágrafos acima) na qual anexou a "Ordem da Bandeira Vermelha", condecoração que tinha obtido em 1928, pois "seria contrário à minha dignidade levá-la ao mesmo tempo que os carrascos dos melhores representantes da classe operária russa”. Vítima de uma cilada da NKVD, Reiss foi assassinado pouco depois em Lausanne (Suíça). Trotsky criticou o modo em que efetuou a sua ruptura: "É inútil dirigir uma carta a Moscou. Não é possível influir em nada sobre esses bonapartistas corrompidos até a medula por meio de uma carta. No dia da ruptura impunha-se difundir uma declaração política à imprensa mundial, que não informasse da passagem de Reiss para a IV Internacional -o que só interessa neste momento a uma ínfima minoria- mas sim de suas atividades passadas na

${ }^{16}$ Carta de Ignace Reiss ao CC do PCUS. In: Poretski, 1972, 10. 
GPU, dos crimes desta, da fraude dos Processos de Moscou e da sua ruptura" (apud PORETSKI, 1972, p. 7).

Trotsky concluía que a ruptura de "Ludwig" (outro codinome de Reiss) era, além de uma atitude corajosa, o índice claro de que "mais de um membro do aparelho de Stalin vacila", embora estes não tirassem a conclusão de Reiss: "Pretendo consagrar minhas humildes forças à causa de Lenin: quero combater, pois somente nossa vitória - a vitória da revolução proletária - libertará a humanidade do capitalismo e a União Soviética do stalinismo! Avante para novos combates pelo socialismo e pela revolução proletária! Pela construção da IV Internacional!" (PORETSKI, 1972).

\section{A política do extermínio}

Pavel Sudoplátov admite o assassinato de Reiss pela NKVD, fornece inclusive os nomes dos executores (o búlgaro Boris Afanasiev e o russo Viktor Pravdin) mas, como de hábito, procura um álibi que não só ignora as motivações políticas, como deforma os acontecimentos até chegar à calúnia: "Reiss, aliás Poretski, era um espião sediado na Europa ocidental, que havia recebido grandes somas de dinheiro, das que não havia prestado contas, e temia ser vítima dos expurgos. Reiss decidiu fazer uso dos fundos operacionais para desertar, e assim foi como depositou dinheiro em um banco norteamericano. Antes de desertar em 1937, Reiss escreveu uma carta à embaixada soviética em Paris denunciando Stalin. A carta conseguiu chegar até uma publicação trotskista; foi um erro decisivo. Do expediente de Reiss, se percebia que nunca havia simpatizado com Trotsky" (P. e A. SUDOPLÁTOV, 1994, p. 78).

Quando isso foi escrito, já se sabia há longo tempo que não "a carta", mas seu autor em carne e osso, tinha se entrevistado com os trotskistas, notadamente com o holandês Henk Sneevliet (deputado na Holanda, ex-funcionário da Internacional Comunista na China sob o codinome "Maring" e, como já foi dito, fundador do PC da Indonésia) antes de redigir a car- ta... (No seu Trotsky, de 1988, Pierre Broué ainda sustentava que os assassinos de Reiss pertenciam ao "grupo de Paris" chefiado por Serguei Efron, com o maffioso Roland Abbiate e a professora suíça Renata Steiner, que tinha tentado seqüestrar Leon Sedov em 1937) (BROUÉ, 1988, p. 871).

Sudoplátov também admite a responsabilidade da NKVD, em agosto de 1938, no assassinato de Rudolph Klement, jovem trotskista alemão, ex-secretário de Trotsky na Turquia, que fora um dos principais organizadores da conferência de fundação da IV Internacional. $\mathrm{O}$ ato foi especialmente atroz, pois Klement foi seqüestrado em Paris, estrangulado e esquartejado num apartamento da NKVD por um certo "Turco": seu tronco apareceu boiando no Sena poucos dias depois. Klement conhecera pessoalmente (em Paris, em 1938) o futuro assassino de Trotsky, Ramon Mercader (então "Jacques Mornard"): "Porquê a GPU atacou Klement? Não era uma personalidade eminente da IV Internacional. Mas a intimidade conseguida com o longo secretariado feito para Trotsky faria dele uma testemunha valiosa nos processos fraudulentos [de Moscou]. Sua coragem e resistência transformaram o seu seqüestro em assassinato?", se pergunta Gérard Rosenthal (ROSENTHAL, 1975).

A conferência de fundação da IV Internacional, em setembro de 1938, realizou-se sob a presidência de honra de Leon Sedov, Erwin Wolf e Rudolph Klement, todos recentemente assassinados. "Em 15 de novembro [de 1938] as duas pernas foram encontradas no Sena, em Garganville, amarradas. Os ossos tinham sido serrados. As pernas adaptavam-se perfeitamente ao tronco...A cabeça nunca foi encontrada. Assim desapareceu em plena Paris, sem que a polícia nunca descobrisse nada, por ter sido o secretário de Trotsky, Rudolph Klement, esquartejado morto ou vivo" (ROSENTHAL, 1975, p. 280-1).

Previamente, a 16 de julho, uma carta dirigida a Trotsky, supostamente assinada por Klement, declarava que o primeiro se transformara em um aliado do 
fascismo, motivo pelo qual o autor se retirava da IV Internacional, preferindo "sumir" do cenário. Depois do aparecimento do corpo, em agosto, Trotsky dirigiu uma terna carta à mãe de Klement, Ruthe, que lhe solicitara informações sobre seu filho, informandolhe tudo o que sabia sobre sua vida, e acrescentando: "Estou certo que a carta era falsa. Contém afirmações falsas e inúteis, emitidas por alguém informado apenas de modo geral e imperfeito das atividades de Rudolf. A semelhança da escrita não é uma prova da sua autenticidade. Não é mais que semelhança: os inimigos de Rudolph dispõem dos melhores especialistas do mundo, que já fizeram várias vezes coisas semelhantes. Isto descarta a hipótese segundo a qual Rudolph teria passado voluntariamente para o campo dos seus inimigos. Nesse caso não teria nenhuma necessidade de se esconder. Ao contrário: se oporia abertamente aos seus camaradas de ontem, se não a deserção careceria de sentido. Nesse caso, também, teria dado um sinal de vida à sua mãe. A situação é clara, não tenho nenhuma dúvida que Rudolph foi assassinado por seus inimigos" (TROTSKY, 1938).

No mesmo ano de 1938, foram exterminados quase todos os remanescentes da "fração bolcheviqueleninista", os trotskistas da URSS, que desde o início dos "processos" (1936) tinham sido reagrupados no campo de concentração de Vorkuta, no círculo polar, com temperaturas inferiores a 50 graus negativos, onde esses quatro ou cinco mil sobreviventes "se recusam a trabalhar mais de oito horas, ignoram sistemáticamente os regulamentos, criticam organizada e abertamente Stalin e a 'linha geral', declarando-se prontos para a defesa incondicional da URSS. No outono de 1936, depois do primeiro processo, organizaram comícios e manifestações de protesto, e depois decidem uma greve de fome, em assembléia geral. Suas reivindicações são, segundo Maria Ioffé [filha do ex-diplomata soviético Abraham Ioffé, sobrevivente dos campos até a década de 90, NDA]: 1) O reagrupamento dos presos políticos, separando-os dos criminosos de direito comum; 2) A reu- nião das famílias dispersas em campos diferentes; 3) Um trabalho conforme à especialidade profissional; 4) $\mathrm{O}$ direito de receberem livros e jornais; 5) A melhora das condições de alimentação e de vida. O menchevique MB acrescenta a jornada de oito horas, o envio para fora das regiões polares dos inválidos, das mulheres e dos idosos. No comitê de greve estão G. J. Iakovin, Sokrat Gevorkian, Vasso Donadzé e Sacha Milechin, todos bolchevique-leninistas, os três primeiros veteranos das greves de fome de 1931 e1933 em Verkhneuralsk" (BROUÉ, 1980 (2)). As condições de "vida" e a repressão vão eliminando àqueles que a IV Internacional tinha definido como "sua seção mais importante": em março-abril de 1938, sob ordens diretas de Stalin, os sobreviventes foram fuzilados em massa.

\section{Um objetivo de Estado}

Da Espanha em guerra, até a gélida Sibéria, passando pela Alemanha nazista, nunca uma organização política sofreu perseguição semelhante, na história moderna. $\mathrm{O}$ assassinato de Trotsky se inscrevia nesse quadro, e não tinha acontecido ainda tanto devido à sua notoriedade e aos cuidados adotados, quanto ao providencial asilo político concedido pelo governo mexicano em 1937. Sem dúvida, já estava na agenda de prioridades da NKVD, antes de 1939, como afirma Lilly Marcou - tendo Sudoplátov admitido que Stalin encomendara a tarefa a Spiegelglass em 1937 (o que não lhe impede de afirmar que "em agosto de 1938, fiquei sabendo, pela primeira vez dos assassinatos e seqüestros de trostskistas e desertores ocorridos na Europa durante os anos trinta") ${ }^{17}$ e tendo, no mesmo ano, estabelecido a investigação suíça sobre

17 P. e A. Sudoplátov, 1994, 78. Esta contradição, entre outras, joga luz sobre o método de confissão-ocultamento que permeia todo o livro de Sudoplátov que, como os de outros ex-agentes (também da CIA) procura resolver o problema de confessar os crimes, defendendo ao mesmo tempo a inocência do autor. 
a morte de Reiss que o já conhecido "executor" Roland Abbiate, e um certo "Martignac" (com certeza um codinome) tinham se dirigido ao México (em março de 1937) no rastro de Leon Trotsky...

$\mathrm{O}$ assassinato de Trotsky tornara-se um objetivo institucional do Estado stalinista, isto é, relativamente independente das circunstâncias políticas imediatas. Era, também, estratégico, pois implicava um grande risco diplomático: assassinar um homem de Estado -e também uma das personalidades políticas mais conhecidas internacionalmente- em uso do seu direito de asilo, em território estrangeiro. Isto significa que a empresa só era possível se se contasse, não só com os meios organizativos (o aparelho internacional da GPU-NKVD), mas também com os meios políticos, isto é, com cumplicidades "diplomáticas" do mais alto nível. Pelos motivos apontados, não deve surpreender que o ato seja consumado num período de relativo "abrandamento" da repressão da URSS.

A 13 de novembro de 1938, o Comitê Central e o Conselho dos Comissários do Povo pronunciaram-se (num texto não publicado) por um abrandamento da repressão. A 8 de dezembro era anunciado que o responsável da NKVD, Ekhov, abandonava o seu posto. Muitos milhares, entre os mais cruéis torcionários da NKVD, forram torturados e fuzilados, por sua vez. Algumas milhares de pessoas foram libertadas, como os futuros marechais Rokossovski e Meretskov, o futuro general Gorbatov, o físico Landau e Tupolev, o construtor de aviões. O número de novas prisões diminuía, mas não parava. Eikhe, ex-membro do Politburo, foi fuzilado em 1940. Numerosos oficiais que tinham servido na Espanha foram presos e fuzilados quando voltaram. Foi o caso de Antonov-Ovseenko (que tinha tomado o Palácio de Inverno em 1917), do general Stern, de Gorev e de muitos outros. É nestas condições que se abre o XVIII Congresso do PCUS, em abril de 1939. Milhões de soviéticos estavam ainda deportados; três membros do Politburo, Tchubar, Eikhe e Postychev, estavam na prisão, prestes a serem fuzilados. Iakovlev foi fuzilado quando transcorria o Congresso. Dos 1827 delegados ao XVIII Congresso, somente 35 tinham estado presentes no XVII Congresso, de 1934 , ou seja apenas $2 \%{ }^{18}$.

Depois da chegada de Trotsky no México, diversos "homens de ação" do aparelho internacional da NKVD chegaram também a esse país, aberta ou clandestinamente, o que se intensificou com a derrota do campo republicano na guerra civil espanhola: o excônsul em Madri, Lev Haikiss, o já mencionado Eitingon, junto com Caridad Mercader, Vittorio Vidali com Tina Modotti ("Maria Ruiz"), que controlava os quadros nas Brigadas Internacionais. Também chegam o venezuelano Enrique Martinez, o ex-guardacostas de Gramsci, Carlo Codevilla, transformado em agente da GPU, o ítalo argentino Vittorio Codovilla ${ }^{19}$. As coisas chegam ao ponto que a 8 de setembro de 1938, o advogado norte-americano de Trotsky, Albert Goldman, faz uma declaração à imprensa: depois das mortes de Wolf, Klement e Sedov, "a GPU está determinada a um esforço desesperado para eliminar o próprio Trotsky". Adverte que "a campanha será levada adiante pelo PC mexicano, com a ajuda de altos funcionários do Ministério de Educação, e por Vicente Lombardo Toledano, que recebeu as instruções necessárias na sua recente visita à Europa".

Bem antes disso, segundo Sudoplátov, a ordem já tinha sido dada por Stalin em pessoa: "Trotsky e seus seguidores significavam uma séria ameaça para a União Soviética ao competir conosco para ser a van-

\footnotetext{
${ }^{18}$ Cf. TUCKER, 1990. Entre os fuzilados, cabe contar os agentes Sergei Efron, Vadim Kondratiev e Roland Abbiate, que protagonizaram as primeiras tentativas de assassinato de Trotsky (coordenados, segundo Sudoplátov, por Spiegelglass): sem dúvida, tratou-se menos de um castigo à ineficiência, do que de uma garantia de discrição, ou "queima de arquivo".

${ }^{19}$ Cf. GALL., 1991. A autora confunde Codevilla con Codovilla.
} 
guarda da revolução comunista mundial. Beria sugeriu que me colocassem no comando de todas as operações antitrotskistas do NKVD, a fim de infligir o golpe decisivo no movimento trotskista. Aquela era a razão para que eu tivesse sido nomeado subdiretor do Departamento do Estrangeiro, sob as ordens de Dekanózov. Minha missão consistiria em mobilizar todos os recursos disponíveis do NKVD para eliminar Trotsky, o pior inimigo do povo. 'No movimento trotskista não há figuras políticas importantes além do próprio Trotsky, disse Stalin. Eliminado Trotsky, a ameaça desaparece'. Dito isto, Stalin voltou a se sentar à nossa frente e começou a falar lentamente de quão insatisfeito estava com o atual estado de nossas operações, que, a seu modo de ver, não eram ativas o bastante." Desmentindo a imagem de super-profissionalismo da NKVD, seu chefe máximo, o célebre Lavrenti Beria, sugeriu que fossem usados para a tarefa os contatos de Alexander Orlov, e que "falássemos com ele [Orlov] em seu próprio nome" (P. e A. SUDOPLÁTOV, 1994, pp. 103 e 108). Ora, Orlov já tinha desertado no ano anterior e, como vimos, tinha contatado Trotsky para advertí-lo das ameaças que pairavam sobre ele: se o conselho de Beria tivesse sido seguido, Trotsky teria sido provavelmente informado com boa antecedência dos planos exatos do seu assassinato (Sudoplátov e Eitingon não o seguiram).

\section{A conexão mexicana}

Em setembro de 1939, os "enviados de Moscou" acusaram alguns dos dirigentes do PC mexicano de "debilidade ante Trotsky". No congresso celebrado nos meses seguintes, formou-se uma comissão especial, secreta, encarregada de planificar "a luta contra Trotsky", dirigida realmente por Vidali, mas presidida "nominalmente", segundo Pierre Broué, por Vittorio Codovilla que, de acordo com o mesmo autor, era um agente da GPU desde fins da década de 20. A questão do assassinato de Trotsky tinha sido posta para a direção do PCM, pelos "enviados internacionais", desde setembro de 1938.

Desde a sua chegada ao México, Trotsky vinha sendo atacado violentamente pela imprensa do PCM. La Voz de Mexico, El Popular e Futuro protestaram contra o presidente Cárdenas pela concessão do asilo; continuavam a pedir a sua expulsão. Esta campanha aumentou em virulência nos primeiros meses de 1940; era conduzida com os chavões habituais "Trotsky, o velho traidor, demonstra que quanto mais velho fica, mais covarde se torna...", "Que peixe escorregadio é este velho traidorzinho!”, “...o novo pontífice, Leon XXX, à vista das trinta peças de prata do Judas sujo..." (El Popular, 1940). Trotsky observou: "esta é a maneira de escrever das pessoas que estão prestes a substituir a caneta pela metralhadora." No dia $1^{\circ}$ de maio de 1940, uma manifestação uniformizada marchou através da Cidade do México, portando bandeiras que diziam "Fora Trotsky!".

Pouco antes, em março do mesmo ano, no congresso do PCM, a sua direção (aparentemente reticente em passar das palavras aos atos) foi "depurada": "Laborde foi excluído do secretariado, [Valentin] Campa do Burô Político, qualificados de sectáriooportunistas, sectários por não terem combatido pela unidade das forças populares, e terem se enfrentado na CTM com Lombardo Toledano, e oportunistas por não terem mantido a independência do partido frente ao cardenismo. A isso, os 'enviados da Europa', acrescentam as acusações de corrupção, provocação, cumplicidade com a maçonaria e o trotskismo. A convocação para o Congresso Extraordinário ( $\mathrm{La}$ Voz de México, 25 de novembro de 1939) chama à exclusão dos traidores, divisionistas, fracionistas, trotskistas, inimigos do povo, agentes do fascismo, almazanistas, corrompidos, infiltrados no passado no partido" (BROUÉ, 1980b, p. 87). Nas suas memórias, Valentin Campa relata que Laborde "tinha-lhe comunicado que um camarada delegado da Internacional Comunista lhe expôs a decisão de eliminar Trotsky, e pediu-lhe 
sua colaboração como secratário-geral do partido, e a de uma equipe adequada para a eliminação... [Laborde] estava convencido de que Stalin participava na eliminação de Trotsky e no uso [para esse fim] da Internacional Comunista. Sempre tinha tido um bom conceito de Stalin, mas...indignado pelas suas manobras, chegou a dizer que Stalin 'era un cabrón'... Desde que saí da prisão, em 1970, insistí perante a direção do PCM na necessidade de esclarecer essas verdades históricas" (CAMPA, 1985, pp. 161-166). Curiosamente, Campa reivindica a campanha antitrotskista do PCM em 1937-1940.

Em 19 de maio de 1940, a Voz de México, principal órgão do Partido Comunista Mexicano, dedicou um artigo ao "velho traidor", como Trotsky era chamado pelo secretário-geral da central de trabalhadores (CTM), Lombardo Toledano. O artigo era extremamente violento e exigia a expulsão de Trotsky do México por suas "atividades anti-proletárias e anti-mexicanas". O general Cárdenas também foi alvo de ataques de dois lados - da burguesia mexicana pró-americana e do PCM. Quando ocorreu uma tentativa de putsch direitista, liderada pelo general Cedillo nas montanhas, os stalinistas acusaram Trotsky de tê-la inpirado. A direita viu, ao contrário, a "mão de Trotsky" no fato de que as companhias de petróleo euro-americanas fossem nacionalizadas: para a direita, Cárdenas era uma marionete, caída nas garras do "exilado vermelho". Mas Trotsky nunca se encontrou com o presidente durante seus anos no México (Cf. DUGRAND, 1992).

Em 24 de maio de 1940, houve o atentado do bando chefiado por Siqueiros. O PCM tentou dele se desvincular (foi apresentado como "elemento incontrolável”) mas, quando retornado em 1942 do "exílio" auto-imposto no Chile (para fugir das acusações e processos), foi recebido pelo mesmo PCM como um herói. No breve período que passou na prisão, em 1941, quem cuidou da sua libertação foi o poeta chileno (vinculado ao PC do seu país) Pablo Neruda, cônsul na Cidade do México, que conta: "David Alfaro Siqueiros estava então na prisão. Alguém o havia embarcado em uma incursão armada para a casa de Trotsky. Conhecio na prisão, mas, na verdade, também fora dela, porque saíamos com o comandante Pérez Rulfo, chefe da prisão, e íamos beber por ali, onde não nos vissem muito. Já tarde na noite, voltávamos e eu me despedia, com um abraço, de David, que ficava atrás das grades... Entre saídas clandestinas da prisão e conversas sobre tudo o que há, Siqueiros e eu tratamos de sua libertação definitiva. Munido de um visto que eu mesmo estampei em seu passaporte, dirigiu-se ao Chile com sua mulher, Angelica Arenales" ${ }^{20}$. E assim Neruda deu sua contribuição ao ocultamento da trama do crime (o embaixador chileno viu-se obrigado a desculpar-se diante do governo mexicano pela atitude inconsulta, e violatória das normas diplomáticas, do seu cônsul).

\section{A defesa desarmada}

Trotsky foi o primeiro a concluir que o público fracasso do atentado de maio não produziria a desistência dos seus perseguidores, mas exatamente o contrário, e assim o declarou numa entrevista jornalística. Inclusive os que acreditam no caráter só "intimidatório" desse ataque, o admitem: "Tudo não passou de um alarde de força feito não só para atemorizar o

\footnotetext{
${ }^{20}$ NERUDA, 1976, p. 168-9. O descaso com que Neruda se refere a Trotsky e ao atentado, o tom de "pilheria irresponsável" com que se refere à participação nele de seu amigo Siqueiros, talvez revelem algo mais do que a imagem de irresponsável bon vivant, mas com "sensibilidade social" ("comunista") que tenta passar de si mesmo na sua autobiografia. A NKVD parece ter trabalhado com três círculos concêntricos: a) O "núcleo político", composto por membros do aparelho russo; b) Os "executores", de todas as nacionalidades, se possível não-russos; c) A "periferia”, na qual tinham seu lugar os "companheiros de estrada" públicos, mas não só eles, que eventualmente podiam desempenhar tarefas de grande importância. Tina Modotti, por exemplo, deve ter tido seu lugar neste nível, assim como, provavelmente, o futuro Prêmio Nobel de Literatura chileno.
} 
ex-Secretário de Guerra, como também para obrigar o governo de Lázaro Cárdenas a decretar a expulsão de Trotsky do país, para não correr o risco de se envolver em uma questão internacional se o político russo fosse morto em território mexicano. Essa estratégia do medo tinha dado certo na Noruega. Mas Lázaro Cárdenas não era como o ministro da Justiça da Noruega, Trygve Lie, e aos stalinistas só restava um caminho para acabar de vez com o exilado soviético: matá-lo" (GARMABELLA, 1972, p. 60).

Trotsky não se fazia, por outro lado, qualquer ilusão quanto a alguma reação nas fileiras "comunistas" diante da perseguição de que era objeto: " $90 \%$ dos revolucionários que construíram o partido bolchevique, fizeram a Revolução de Outubro, criaram o Estado Soviético e o Exército Vermelho, dirigiram a guerra civil, foram exterminados como traidores nos últimos doze anos. Em troca, o aparelho stalinista acolheu nesse período a imensa maioria dos que estavam do outro lado da barricada nos anos da revolução...Por meio de exclusões permanentes, pressões materiais, corrupção, expurgos e execuções, a camarilha totalitária do Kremlin transformou completamente o Comintern em instrumento dócil. A sua atual camada dirigente, como as suas seções, compreende homens que não se uniram à Revolução de Outubro, mas à oligarquia vitoriosa que distribui títulos políticos elevados e favores materiais" (TROTSKY, 1978-88, vol.24, p. 313).

Que precauções adotou Trotsky, diante dessa perspectiva, além da fortificação da sua casa? Este ponto deu lugar a controvérsias. O "sistema de segurança" de Trotsky era amador, ele o sabia e assim o declarou a um jornalista: "Alguns jornais dizem que eu 'alugo' para a minha guarda só estrangeiros, mercenários. Isto é falso. Minha guarda existe desde o meu exílio na Turquia, há doze anos. Sua composição mudou de acordo com o país em que me encontrava, embora alguns tenham me acompanhado de um país a outro. Sempre esteve composta de jovens camaradas, vinculados pela identidade de idéias políticas, e escolhidos pelos meus amigos mais velhos e experimentados entre voluntários que nunca me faltaram" (TROTSKY, 1978-88, p. 314).

Além disso, continuou na casa do revolucionário o desfilar de dirigentes políticos, amigos, reuniões, etc. Isto sem dúvida facilitou a "infiltração" daquele que seria finalmente seu assassino, que exibia uma conduta que, para Isaac Deutscher, devia ter levantado suspeitas muito antes: "Este exibia um desinteresse tão completo pela política que sua atitude parecia beirar a indolência mental, algo muito surpreendente no culto 'filho de um diplomático'. Tinha relações impenetravelmente obscuras no comércio e jornalismo; e seus antecedentes familiares eram enigmáticos. As histórias que contou a Sylvia sobre si mesmo eram estranhas e incoerentes; e gastava dinheiro aos montes, como se o sacasse de uma bolsa da abundância eterna, com festas e diversões" (DEUTSCHER, 1969, p. 434). Para Pierre Broué, o risco da infiltração era inevitável dada a atividade e os objetivos políticos de Trotsky: "Estava condenado a viver os poucos anos que lhe restavam na plena consciência de que existiam pessoas como os irmãos Sobolevicius, tomando as precauções indispensáveis, mas sem parar de correr os riscos necessários à continuidade de uma vida militante e de combate. A conclusão se impunha: nesse quadro, os assassinos só poderiam ganhar" (BROUÉ, 1980b, p. 52).

Nos anos 70, um grupo trotskista inglês, chefiado por Gerry Healy, acusou os responsáveis pela guarda de Trotsky (basicamente, a direção do SWP americano, em primeiro lugar Joseph Hansen) de cumplicidade com a NKVD-GPU e com... a CIA, e portanto com o assassinato. A acusação baseou-se em indícios circunstanciais, e muito fracos (a comprovada relação entre Hansen e um membro da NKVD, por exemplo, era reconhecido do próprio Trotsky) e a campanha feita em torno dela não teria qualquer transcendência se não tivesse tido como principal porta-voz a atriz inglesa Vanessa Redgrave, e seu irmão, também ator, Corin, ambos membros do grupo de Healy ${ }^{21}$. O outro indício, 
a sempre suspeitada participação de um dos guardacostas americanos de Trotsky no atentado de 24 de maio, Robert Sheldon Harte (o pai de Harte era amigo pessoal do chefe do FBI, J. Edgar Hoover) ${ }^{22}$, foi definitivamente desfeito nas memórias de Sudoplátov, que esclarece que esse não era o caso, e também os motivos do assassinato de Harte (o que, de passagem, dá razão póstuma a Trotsky, que sustentou contra a polícia mexicana, e seu chefe Sánchez Salazar em particular, que Harte jamais fora um agente).

\section{O trabalho do Sr. Mercader}

Ramon Mercader fez um trabalho de longo prazo (mais de dois anos), onde não faltaram os erros e as vacilações. Desde 1938, segundo Sudoplátov, "seguindo instruções de Eitingon, absteve-se de toda ativida-

${ }^{21}$ Cf. AAVV, 1976. Toda a "responsabilidade" de Harte parece ter sido a de conhecer um agente, Ióssif Grigúlevitch, a quem Sudoplátov empresta o codinome "Padre" (e que provavelmente seja o mesmo que em outros depoimentos é referido pelo inacreditável codinome de "Pedro Cheka"), que era supostamente tambem conhecido por outros trotskistas como "politicamente neutro", e que foi o responsável pela abertura das portas da casa de Coyoacán no atentado de 24 de maio de 1940 (o que também desmente a versão de que o próprio Mercader teria enganado Harte nessa ocasião). Harte, segundo Sudoplátov, foi assassinado para que não revelasse a verdadeira condição de Grigúlevitch.

${ }^{22}$ Em um relatório interno do FBI, Hoover acusou Hansen e outros dirigentes do SWP de terem assassinado "George Mink" (codinome, provavelmente, do lituano Dimitri Utnik, de acordo com o historiador catalão Albert Balcells), "executor" russo da GPU-NKVD residente nos EUA (responsável reconhecido pelo asssassinato dos libertários italianos Camillo Berrneri e Francesco Barbieri) jogando seu cadáver na crátera de um vulcão. "Mink" estava no México no período da preparação do assassinato de Trotsky, e era procurado pelos trotskistas. Hansen, por outro lado, fraturou seu braço batendo em Ramón Mercader, logo depois do assassinato, todos comportamentos curiosos para um "agente do FBI e da GPU". de política. Seu papel consistia em fazer-se de amigo, que ocasionalmente dava apoio financeiro, mas sem desempenhar nenhum papel político". A sua linha geral de atuação foi lembrada pela última testemunha ainda viva do crime de Coyoacán, Seva Volkov, neto do Trotsky: "O pseudo-belga, Jacson Mornard, começou a cultivar a amizade dos guardas. Era uma pessoa muito generosa, amável e prestativa. Levava os guardas para comer, convidou-os para o casamento de Otto Rühle, às vezes também convidava Charles Cornell, um professor primário norte-americano, e um dos guardas. Cultivava a amizade do casal Rosmer. Chegou a darme pequenos presentes e levou-me ao campo, juntamente com Margarite e Alfred [Rosmer]. Porém nunca mostrou interesse em agradar Leon Trotsky. Algumas vezes, casualmente, encontravam-se no jardim e Mornard apenas o saudava. Uma vez, apresentou a sua companheira Sylvia e nada mais. Assim foise criando a imagem de um homem que queria ajudar e ser amável com os camaradas"23.

Em 17 de agosto de 1940, teve uma primeira ocasião (ficou a sós com Trotsky, no seu gabinete, mantendo uma atitude nervosa, que chamou a atenção deste) que não a aproveitou: "Mercader ou Mornard ou Jacson, mostrou sinais de sua angústia -ficou doente; espalhou pistas que poderiam expor sua falsa identidade. Pode ser que para se sentir mais confiante para o assassinato, tenha precisado de um ensaio geral. Os criminosos e a polícia, como Trotsky observara, parecem necessitar de cenários como nas

${ }^{23}$ VOLKOV-TROTSKY, 1992, p. 315. Este texto é a transcrição do depoimento que o neto de Trotsky fez no simpósio internacional que organizamos, no Departamento de História da USP, em setembro de 1990 , por ocasião do $50^{\circ}$ aniversário do assassinato. Segundo Pierre Broué, também presente, foi a mais completa relação dos fatos realizada pelo único sobrevivente atual dos acontecimentos de agosto de 1940. 
peças de teatro. Ou, diante de Trotsky, a sós no escritório, Jacson pôde simplesmente ter-se sentido sem jeito" (MOSLEY, 1972, p. 148). Ainda assim, Trotsky tornou a recebê-lo três dias depois, quando Mercader consumou o atentado mortal. Sobre a mesa de Trotsky restou seu último escrito, inconcluso, cujo parágrafo final, o último que escreveu, adaptava-se perfeitamente ao cenário: "Houve mais obstáculos, dificuldades e etapas, na estrada do desenvolvimento revolucionário do proletariado, do que previram os fundadores do socialismo científico. $\mathrm{O}$ fascismo e a série de guerras imperialistas são a terrível escola através da qual o proletariado deverá libertar-se das tradições pequeno-burguesas e das superstições, desembarçar-se dos partidos oportunistas, democráticos e aventureiros, forjar e educar a vanguarda revolucionária, preparando assim a solução da tarefa fora da qual não há saída para o desenvolvimento humano..." (TROTSKY, maio-agosto 1940, p. 376).

No dia seguinte, antes de morrer, suas últimas palavras foram: "Estou certo da vitória da IV Internacional. Avante!", seguidas de um "Natalia, te amo", dirigido a sua esposa. E o fim.

Dois dias mais tarde, o Pravda ("Verdade") de Moscou anunciava simplesmente: "Tendo ultrapassado ainda mais os limites do aviltamento humano, Trotsky ficou preso em sua própria rede e foi assassinado por um dos seus discípulos". Uma década e meia depois, no seu Informe Secreto ao XX Congresso do PCUS, Kruschev denunciava os crimes de Stalin (morto em 1953) ${ }^{24}$, mas legitimava a eliminação de Trotsky...

O assassino, obviamente, não negou o crime: atribuiu-o à “impulsão súbita” de um discípulo desiludi-

\footnotetext{
${ }^{24}$ Provavelmente envenenado pelos seus colegas do Politburo do PCUS, temerosos de um novo expurgo que os atingisse desta vez: é o que insinuou seu "braço direito" durante longos anos, depois caído no ostracismo, Lazar Kaganovitch. Cf. Kahan, 1987.
}

do. O informe da polícia mexicana, no entanto, não deixou dúvidas: além do picão de alpinista usado no crime, nas roupas do ainda chamado "Mornard" "encontrava-se uma bainha de couro cor de café, banhada em prata, com um punhal de 35 centímetros de comprimento e três de largura, e o punho de metal cinzelado (...) Além disso, foi encontrada com o assassino uma pistola Star, calibre 45, número de registro P.195-264, com oito balas no pente e uma no cano. Todas essas armas demonstravam que o assassino estava disposto a matar Trotsky de qualquer maneira. Por que usou o picão ao invés da pistola? Sem dúvida, para evitar o ruído da detonação. Tinha evidentemente a intenção de fugir após desferir o golpe mortal....'. No primeiro informe policial, Mercader era ainda chamado de "Raft Jakkson" (sic) ${ }^{25}$.

Nos depoimentos posteriores, feitos à polícia mexicana, Mercader incorreu em todo tipo de contradições e de faltas de verossimilhança, sempre negando qualquer vínculo com a GPU-NKVD. Sua declaração, feita na carta, de que Trotsky era um agente do imperialismo americano (ainda estava vigente o pacto Hitler-Stalin) mudou em menos de um ano, depois da invasão da URSS pela Alemanha, para "agente da Gestapo", o que valia por uma confissão. Em pouco tempo, verificou-se que falava um perfeito espanhol (o que ele negara) com sotaque catalão.

Menos de duas semanas depois do crime, o Juiz encarregado da Instrução, Raúl Carrancá Trujillo, recebeu uma carta anônima em que era ameaçado: "Qualquer ação que você faça no processo que acusa Jacques Mornard pelo homicídio de Trotsky, que tenha que fazê-lo declarar que é agente da GPU e em

\footnotetext{
${ }^{25}$ As atas policiais completas, tanto do atentado de 24 de maio como do assassinato de 20-21 de agosto, encontram-se nos Arquivos da Generalitat de Catalunya. Agradecemos a Enric Mompó Martinez, da Universidade Central de Barcelona, o acesso a esses documentos.
} 
consequência esclarecer uma questão internacional de profunda e gravíssima transcendência, você pagará muito caro. Lembre-se de que a ação poderosa de uma organização perfeita se infiltrou até uma mansão que se acreditava inatacável. Limite-se a buscar uma causa ordinária sem pretender, no mínimo que for, ir além das fronteiras do assunto tratado. Não se esqueça, camarada Juiz, que você pode ser premiado ou castigado segundo sua atuação. Não se esqueça e tenha sempre presente, durante o julgamento, que há mil olhos sobre você, de todas as raças, que vigiam seus atos. Saudações, camarada" ${ }^{26}$.

\section{Um "homem de aço"?}

Nos vinte anos posteriores, preso, Mercader não rompeu o seu silêncio a respeito dos seus vínculos com a GPU-NKVD, o que lhe deu fama de "homem de aço". Sua vida na prisão -que parece ter incluído um caso amoroso com sua diretora, vinculada ao PCM, e que incluiu a celebração de um matrimônio com outra mexicana- não parece justificar a fama, pois pouco pareceu-se com uma vida de sofrimentos. A revista italiana $O g g i$ informava, a 23 de outubro de 1951, que "alguém continua cuidando dele por todos esses anos; alguém, pagando generosamente, providenciou que se garantissem a ele todas as comodidades de que se pode dispor numa prisão (e nas prisões mexicanas tais comodidades são muitas e notórias). A cela número 27 da penitenciária Juárez não fica muito atrás de um bom apartamento de hotel. Basta ter o dinheiro para pagar tais luxos e, no caso do assassino de Trotsky, esse dinheiro jamais falta."

A figura do "homem de aço", exaltada por Nicolás Guillén, entre outros, é combatida pela testemunha Seva Volkov, que presenciou os momentos seguintes

\footnotetext{
${ }^{26}$ Cf. para um relato minucioso do inquérito policial e suas circunstâncias o livro já citado do General Leandro A Sánchez Salazar.
}

ao crime: "Muitas pessoas na porta, policiais, um carro mal-estacionado... Rapidamente senti uma angústia interior. Sabia que algo acontecera e, ao mesmo tempo, o temor de que tivesse sido algo grave. Ocorreu-me que, da outra vez, havíamos tido sorte, porém já era ir contra o destino que na primeira ocasião fora driblado. Apressei os passos. Vi a porta aberta e entrei em casa. Imediatamente encontrei um dos guardas, Harold Isaacs, todo agitado e perguntei o que estava acontecendo. A única coisa que pude ouvir, pois ele se afastara, foi ‘Jacson, Jacson...'. Eu não entendia o que isto teria a ver com tudo o que estava se passando. Efetivamente, quando atravessei o jardim, vi dois policiais detendo um homem que era, de fato, o famoso stalinista que mais tarde receberia a Legião de Honra. Era um autêntico covarde. Guinchando, lamentando-se, queixando-se de dores. Realmente apresentava algumas manchas de sangue, pois havia sido golpeado. A sua triste figura significava um grande contraste com os trotskistas que foram levados aos campos de concentração e extermínio da URSS, onde foram mortos. Este era o suposto herói stalinista, em oposição aos prisioneiros políticos trotskistas dos campos de Vorkuta, de Kolyma, que morriam sem claudicar e proclamando vivas à revolução, a Lenin e a Trotsky." (VOLKOV-TROTSKY, 1992, p. 317).

Em 1952, ainda na prisão, fez um depoimento frio a La Nuova Stampa (de 18 de novembro) acerca do crime, onde confundiu o tema do artigo que lhe serviu de pretexto para ficar a sós com Trotsky, de modo significativo, referindo-o a uma frase inconexa que Trotsky pronunciara em sua agonia, que Mercader sem dúvida conhecia (pois já tinha sido publicada): "Abriram-me a porta e encontrei Trotsky no quintal, ocupado em dar comida aos coelhos. Disse-lhe que eu tinha um artigo de estatística muito interessante sobre a França e ele me convidou para entrar no escritório, assim como eu havia previsto. Fiquei de pé, à sua esquerda. Coloquei minha capa impermeável sobre a escrivaninha, a fim de tirar o picão de alpi- 
nista que estava no bolso. Decidi não perder a excelente oportunidade que surgira para mim, e no momento preciso em que Trotsky começava a ler o artigo que me servira de pretexto, saquei o picão da gabardina, segurei-o fortemente e desfechei-lhe um violento golpe na cabeça. Trotsky se atirou contra mim, mordeu minha mão, obrigando-me a soltar o picão. Lutamos, entrou gente no escritório e me golpearam. Implorei aos secretários de Trotsky que me matassem, mas não quiseram fazê-lo." Na verdade, como vimos, fora Trotsky que impediu-os de fazê-lo.

O único traço de personalidade de Mercader que se tornou visível, para os não-íntimos, durante a sua prisão, foi uma espécie de esquizofrenia teatral: “Tornou-se teatral e, a princípio, exageradamente encantador para as pessoas que vinham vê-lo; a seguir, ao se defrontar com as perguntas difíceis, ficava outra vez imóvel, de olhos fixos e mãos trêmulas; ou remexia os cigarros e espalhava as cinzas e fagulhas por toda a roupa. Repentinamente começava a falar sem parar, incoerente outra vez, antes de escapar e fingir que era surdo. Demonstrava certo desprezo pelos psiquiatras. Ria e lhes contava histórias de caipiras que 'não enxergavam além da ponta dos narizes'. Ocasionalmente, realizava uma espécie de pantomima, representando os vários papéis diferentes que pareciam querer dele, e fazendo várias vozes diferentes" (MOSLEY, 1972, p. 153).

Outros agentes que estiveram perto de Trotsky manifestaram distúrbios de conduta, como o já mencionado Sobolevicius ("Soblen"), que tornara-se psiquiatra conhecido nos EUA e que, preso, tentou se matar em 1957, engolindo quase "meio quilo de pregos e parafusos" (!) na Penitenciária de Lewisburg (finalmente suicidou-se em 1962). De acordo com Sudoplátov, "Mercader estava preparado para três alternativas: matar Trotsky com um tiro, apunhalá-lo ou matá-lo a golpes”. Quando Mercader, já livre, se encontrou com Sudoplátov em Moscou, em 1969, confessou: "Eu, que tinha morto um guarda a faca- das na guerra civil espanhola, fiquei paralisado pelo grito do Trotsky". Em consequência, "quando a mulher de Trotsky apareceu com os guarda-costas, Mercader estava paralisado e não conseguiu usar o revolver" (P. e A. SUDOPLÁTOV, 1994, pp. 115-116). O último grito e a última resistência do revolucionário permitiram prender seu assassino, o que contribuiria decisivamente a desvendar o crime e a trama existente por trás dele (caso Mercader não fosse preso, é provável que o mistério do assassinato existisse até hoje).

A fama de "homem de aço", por outro lado, parece ter existido só entre os "companheiros de estrada" dos PCs, não entre os profissionais do aparelho. Pouco se sabe sobre a vida de Mercader, livre e condecorado em Moscou, salvo que foi "infeliz" (embora recebesse, como comprovam os arquivos, "uma pensão equivalente à de um general de divisão aposentado"), talvez pelo motivo apontado por Jorge Semprún, que conhecia esse mundo de perto (foi dirigente clandestino do PC espanhol), no seu romance semi-autobiográfico, ao relatar uma conversa (imaginária?) entre dois "agentes" a respeito do seu célebre colega: "- Este inverno, em Moscou, foi-me mostrado [Mercader]. No Bolshoi, dizia Walter. Um desamparo abjeto: assim se podia qualificar a expressão desse homem. /E o que faz lá?, perguntava Herbert. /Nada, dizia Walter. Tem uma datcha, uma pensão por velhice. Ninguém lhe fala/ Walter ria. Atualmente, não se morre. Ás vezes me pergunto se isso é melhor" (SEMPRÚN, 1970, 117).

\section{Um drama inconcluso}

O assassinato de Trotsky não foi o "episódio final" da caçada, o que demonstra que não foi um ato isolado nem pessoal. O general Dmitri Volkogonov, o primeiro a publicar pesquisas baseadas na parte fechada dos arquivos da KGB publicou, durante a perestroika, um artigo revelador, com uma conclusão deliciosa: "Pouco tempo depois da notícia da morte de Trotsky, foi dada a ordem de 'liquidar os trotskistas ativos nos 
campos'. E, na véspera da guerra, houve uma nova onda silenciosa, que varreu as últimas pessoas condenadas por 'trotskismo ativo'. [Os campos de] Petchura, Vorkuta, Kolyma, foram as testemunhas mudas de uma vingança que entoou o réquiem da luta contra o dirigente assassinado da IV Internacional. Stalin não queria compreender que matar alguém era um modo ineficaz de combater suas idéias" (PRAVDA, 1988).

No plano internacional, "penetrar nos grupos trotskistas continuou sendo de máxima prioridade para o serviço secreto soviético em 1940. Como saberíamos o que se passava no movimento trotskista depois de matar Trotsky? Continuariam os trotskistas sendo um perigo para Stalin depois de perderem seu líder? Stalin lia regularmente os informes do agente que haviamos infiltrado no jornal trotskista de Nova Iorque...lia amiúde artigos e documentos trotskistas antes que fossem publicados". Stalin, portanto, ao contrário dos observadores superficiais, sabia, pela sua própria experiência no bolchevismo, que a importância de um partido não se mede pelo seu número circunstancial de adeptos, mas pela força das suas idéias. Segundo o mesmo depoimento, "depois do assassinato de Trotsky, vários membros da rede dos EUA e México foram incorporados a outros ilegais da região. Essa rede ampliada teria um valor incalculável no hora de obter os segredos da primeira bomba atômica" (P. e A. SUDOPLÁTOV, 1994, p. 113 e 121).

Uma última questão deve ser abordada, que se contrapõe ao terror staliniano visto como "circunscrição da alteridade", onde se articulariam harmoniosamente "planejamento (econômico), coletivização, industrialização e campos de concentração" (LEFORT, 1976, p. 96). Trata-se do papel dos governos do "mundo livre" na perseguição aos anti-stalinistas da URSS, e a Trotsky em particular. Esses governos legitimaram os "Processos de Moscou" através do envio de observadores oficiais dos poderes judiciários respectivos. Já vimos a cumplicidade stalino-nazista na Noruega, em relação a Trotsky, bem antes do "pacto germano-sovi- ético" de 1939. Pierre Broué põe o dedo na ferida quando constata que "o atentado foi evidentemente obra de Stalin, mas isso não exclui que tenha sido realizado em aliança concreta com Hitler, e não se pode duvidar que Churchill, se consultado, teria dado seu aval. A eliminação de Trotsky é uma necessidade absoluta, no momento em que a guerra explode, abrindo o risco de uma revolução que a concluísse. O atentado (de maio 1940) falido, os assassinos fizeram funcionar a máquina de intoxicar destinada a enfraquecer a defesa, e a criar condições mais favoráveis para uma segunda tentativa que não demoraria" (BROUÉ, 1987, p. 19).

$\mathrm{Na}$ véspera do assassinato de Trotsky, jornais americanos alertavam para o perigo da "instalação de um governo revolucionário no hemisfério norte", devido à presença do líder bolchevique. Podiam os serviços secretos americanos (FBI) desconhecer os planos do assassinato, em um país que forma parte de sua "área de segurança", e onde seus agentes circulam livremente? O establishment americano odiava Trotsky em uma medida só comparável ao seu temor pelo "comunismo". O Departamento de Estado negou-lhe asilo político em 1933; a imprensa ianque hostilizou o México por lhe haver dado refúgio; em 1938, a chancelaria rechaçou sua entrada temporária, mesmo quando havia sido convidado por uma Comissão parlamentar (a Comissão Dies). Morto Trotsky, o Departamento de Estado proibiu a entrada de suas cinzas, solicitada pelos trotskistas norte-americanos para realizar um ato de homenagem.

Nos anos posteriores ao assasinato, a viúva de Trotsky, Natalia Sedova, que continuou a viver no México, recebeu ameaças de morte (em 1941), ${ }^{27} \mathrm{e}$ viu-se obrigada a desmentir um suposto "testamento" -fraudado- de Trotsky, em que este renunciava e denunciava a revolução socialista, provando tratar-se de uma nova falsificação da NKVD (SEDOVA

\footnotetext{
${ }^{27}$ Informação contida em: Alba, sdp.
} 
TROTSKY, 1948). Quando a publicação das memórias do ex-dirigente do PC americano e ex-agente da GPU nos EUA, Louis Budenz, jogou alguma luz sobre a trama da conspiração para matar seu marido, solicitou um re-interrogatório de Mercader -ainda "Mornard"- e publicou um artigo que concluía: "A responsabilidade do crime de Coyacán -e de tantos outros- recai diretamente, muito mais que sobre miseráveis agentes secretos, sobre Stalin, que os concebeu, ordenou e pagou. Uma investigação completa exigiria a extradição de Stalin, que deveria ficar a disposição dos tribunais mexicanos. Em qualquer hipótese, será Stalin quem responderá perante a opinão do mundo, perante o porvir, perante a história" (SEDOVA TROTSKY, 1947).

Um silêncio ensurdecedor acompanhou a luta da pequena (fisicamente) mulher, que perdeu seu marido e seus dois filhos, assassinados pelo stalinismo, e que era uma militante revolucionária desde inícios do século. A história "oficial” não respondeu: inclusive o regime de Gorbachov negou-se a reabilitar Trotsky, para não falar do regime nascido dos acontecimen-

\section{Bibliografia}

AAVV. Is a Shameless Frame-up! A statement on the slanders circulated by the Healy Group against Hansen, Novack, and the SWP, 1976.

ALBA, Victor (sdp). Trotsky visto por Natalia Sedova, manuscrito inédito, Arquivo da Generalitat de Catalunya. Dos Revolucionarios. Andreu Nin y Joaquin Maurin. Madri, Ediciones Castilla, 1975. tos de 1991, que o inclui na lista das pessoas que nunca deveriam ter nascido (Boris Kagarlitsky afirmou que o furor literário contre Trotsky foi, no regime atual da Rússia, comparável ao do período stalinista). ${ }^{28} \mathrm{~A}$ análise objetiva do assassinato leva à conclusão de que, nele, concentrou-se toda a força da reação do velho mundo, daquele passado do qual "se devia fazer tabula rasa", contra a esperança de um novo mundo que, para toda a humanidade, abriu-se em outubro de 1917. Não foi, portanto, apesar de Hobsbawm, um episódio marginal, mas sim um acontecimento situado no olho do furacão que arrasaria o mundo nos anos sucessivos, no centro do drama que o século XX passou, não intocado, mas também não essencialmente modificado, para o século XXI. Para que a História possa cumprir seu papel desvendador do passado - um passado que, devidamente mitificado, serve de base legitimadora para as ideologias do presente - é preciso que, previamente, seja capaz de restablecer as verdades históricas mais elementares acerca dos processos e acontecimentos fundadores da nossa contemporaneidade.

ANDREW, Christopher Andrew, e GORDIEVSKIJ, Oleg . La Storia Secreta del KGB. Milão, Rizzoli, 1996.

BARCKHAUSEN-CANALE, Christiane. No Rastro de Tina Modotti. São Paulo, Alfa-Omega, 1989.

BARRON, John. KGB Today. The hidden hand. Londres, Hodder \& Soughton, 1985.

\footnotetext{
${ }^{28}$ Cf. Kagarlitsky, 1997.
} 
BAYNAC, Jacques. Post-face. In: Jan Valtin. Sans Patrie ni Frontières. Paris, Jean Claude Lattès, 1975.

BOLLOTEN, Burnett. El Gran Engaño. Las izquierdas y su lucha por el poder en la zona republicana. Barcelona, Caralt, 1975.

BOUKHARINA, Anna L. Boukharina. Boukharine ma Passion. Paris, Gallimard, 1989.

BROUÉ, Pierre. L'Assassinat de Trotsky. Bruxelas, Complexe, 1980a.

Les trotskistes en Union Soviétique. Cahiers Leon Trotsky $\mathrm{n}^{\circ}$ 6, Paris, ILT, 1980b.

Ljova, le "fiston". Cahiers Leon Trotsky n 13, Paris, 1983.

Trotsky. Paris, Fayard, 1988.

BROUÉ, Pierre/VACHERON, Raymond. Meurtres au Maquis. Paris, Grasset \& Frasquelle, 1997.

BUBER-NEUMANN, Margarethe. Historia del Komintern. Barcelona, Picazo, 1975

CAMPA, Valentin. Mi Testimonio.Memorias de un militante comunista. México, Ediciones de Cultura Popular, 1985.

CATE, Curtis. Malraux. São Paulo, Scritta, 1995.

COSTA-AMIC, Bartomeu. Leon Trotsky y Andreu Nin. Dos asesinatos del stalinismo. Cholula, Altres Costa-Amic, 1994.

COULONDRE, Robert. De Stalin à Hitler. Souvenirs de deux ambassades. Paris, Hachette, 1950.

DEUTSCHER, Isaac. Trotsky. El profeta desterrado (1929-1940). México, ERA, 1969.

DUGRAND, Alain. Trotsky in Mexico 1937-1940. Manchester, Carcanet, 1992.

DZIAK, John J. Chekisty. A history of the KGB. Lexington, DC Heath, 1988.

EL POPULAR. México, janeiro 1940 (exemplares diversos).

ELLENSTEIN, Jean. O Estalinismo. História do fenômeno estaliniano. Póvoa de Varzim, Europa-América, 1976.

FISCHER, Ruth. Trotsky à Paris, 1933. Cahiers Léon Trotsky n ${ }^{\circ}$ 22, Paris, junho 1985.

FREITAS, Maria Teresa de. Trotsky e Malraux: sobre o marxismo na literatura. In: Osvaldo Coggiola. Trotsky Hoje. São Paulo, Ensaio, 1994.

GALL, Olivia. Trotsky en México y la Vida Política en el Periodo de Cárdenas 1937-1940. México, ERA, 1991.

GARMABELLA, José Ramón. Operação Trotsky. Rio de Janeiro, Record, 1972.

HÉMERY, Daniel. Révolutionnaires Vietnamiens et Pouvoir Colonial en Indochine. Paris, François Maspéro, 1975.

HOBSBAWM, Eric. Era dos Extremos. O Breve Século XX, 1914-
1991. São Paulo, Companhia das Letras, 1994.

HOOKS, Margaret. Tina Modotti. Fotógrafa e revolucionária. Rio de Janeiro, José Olympio, 1997.

JOUBERT, Jean-Pierre. L'affaire Kirov commence en 1934. Cahiers Leon Trotsky n 20, Paris, dezembro,dezembro 1984.

KAGARLITSKY, Boris. A Desintegração DoMonolito. São Paulo, Edunesp, 1997.

KAHAN, Stuart. The Wolf of the Kremlin. Nova Iorque, William Morris, 1987.

KRIVINE, Jean Michel Krivine/KAHN, Marcel-Francis. La mort de Leon Sedov. Cahiers Leon Trotsky ${ }^{\circ}{ }^{\circ}$ 13, Paris,março 1983.

KRIVITSKY, Walter G. In Stalin's Secret Service. Nova Iorque, 1939.

LEFORT, Claude. Un Homme en Trop. Paris, Seuil, 1976.

LEQUENNE, Michel. Les demi-aveux de Zborowski. Cahiers Leon Trotsky n 13, Paris, março 1983.

LEVINE, Isaac Don. L'Homme qui a tué Trotsky. Paris, Gallimard, 1960.

MALIA, Martin. Comprendre la Révolution Russe. Paris, Seuil, 1980.

MARCOU, Lilly. Stalin Vita Privata. Roma, Riuniti, 1996.

MARKIN, N. In: Biulleten Opositsii n 14, Paris, agosto 1930.

MEDVEDEV, Roy. Le Stalinisme. Origines, histoire, conséquences. Paris, Seuil, 1972.

People's Commissariat of Justice of the URSS. Report of Court Proceedings in the case of the Anti-Soviet "Bloc of Rights and Trotskyites". Moscou, 1938.

MOSLEY, Nicholas. The Assassination of Trotsky, Nova Iorque, Josef Schaftel, 1972.

NERUDA, Pablo. Confieso que he Vivido. Buenos Aires, Circulo de Lectores, 1976.

ORLOV, Alexander. The Secret History of Stalin's Crimes. Nova Iorque, 1953.

PORETSKI, Elisabeth K. Les Notres. Vie et mort d'un agent soviétique. Paris, Denöel, 1969. Nuestra Propia Gente. Madri, Zero, 1972.

PRAVDA, Moscou, 9 de setembro 1988.

ROCHE, Gérard. Les intellectuels américains et la Commission Dewey. Cahiers Leon Trotsky n 42, Paris, ILT, julho 1990.

ROGOVIN, Vadim. 1937. Stalin's year of terror. Londres, Oak Park, Mehring Books, 1998.

ROSENTHAL, Gérard. Avocat de Trotsky. Paris, Robert Laffont, 1975. 
SÁNCHEZ SALAZAR, Gal. Leandro A. Así Asesinaron a Trotski. México, La Prensa, 1955.

SEDOV, Leon. Le Livre Rouge des Procès de Moscou. Paris, La Pensée Sauvage ( $1^{\circ}$ ed., Paris, 1936), 1981.

SEDOVA TROTSKY, Natalia. "La culpabilidad de Stalin en el asesinato de Leon D. Trotsky", Novedades, México, (21 de abril de 1947).

Demanda de Natalia Sedova contra "FranceDimanche". Excelsior, México, 8 de maio de 1948.

SEMPRÚN, Jorge. La Segunda Muerte de Ramón Mercader. Caracas, Tiempo Nuevo, 1970.

SERGE, Victor. Mémoires d'un Révolutionnaire. Paris, Seuil, 1978.

STALIN, Joseph. Rapport au XVII Congrès du PCUS. Paris, Éditions Sociales, 1934.

SUDOPLÁTOV, Pavel /SUDOPLÁTOV, Anatoli. Operaciones Especiales. Barcelona, Plaza \& Janés, 1994.
TREPPER, Leopold. O Grande Jogo. Lisboa, Horizonte, 1977. TROTSKY, Leon. Uma lección trágica. In: Elisabeth K. Poretski. Nuestra Propia Gente. Madri, Zero, 1972.

Lettre à Pagenel. Oeuvres. Vol. 18, Paris, 24 de outubro 1938 . lares. (sdp). Diário do Exílio. São Paulo, Edições PopuStalin. México, Juan Pablos, 1973. Oeuvres. Paris, ILT, 1978-1988.

TUCKER, Robert C. Stalin in Power. Revolution from above. Nova Iorque, Norton, 1990.

VASSETSKI, Nikolai. Lev Trotski: um rosto por trás do vitral da história. Sputnik n 4, Moscou, abril 1990.

VOLKOV-TROTSKY, Esteban. Leon Trotsky: lembranças e significado. In: Osvaldo Coggiola. Trotsky Hoje. São Paulo, Ensaio, 1992.

WALD, Alan. La Commission Dewey 40 ans après. Cahiers Léon Trotsky nº 3, Paris, ILT, 1979.

Endereço do Autor: Av. Prof. Lineu Prestes, 338 - Cidade Universitária - São Paulo - SP - Brasil - CEP 05508-900 - Tel (0xx)11- 3818-3150/ 3701/3731 - Fax: (0xx)11- 3032-2314 